\title{
Real-time PCR for quantification of viable Renibacterium salmoninarum in chum salmon Oncorhynchus keta
}

\author{
Kunio Suzuki ${ }^{1, *}$, D. K. Sakai ${ }^{2}$ \\ ${ }^{1}$ Eastern Hokkaido Inland Water Fisheries Section, The Hokkaido Fish Hatchery, Notorominato 1-1, Abashiri, \\ Hokkaido 093-0131, Japan \\ ${ }^{2}$ Faculty of Bio-industry, Tokyo University of Agriculture, Yasaka 196, Abashiri, Hokkaido 099-2493, Japan
}

\begin{abstract}
Quantification of msa gene mRNA of Renibacterium salmoninarum, the causative agent of bacterial kidney disease (BKD), was investigated using reverse transcription followed by real-time PCR assay on $R$. salmoninarum in culture, and in experimentally challenged chum salmon Oncorhynchus keta fry kidney tissues (total of 70 samples) after intraperitoneal (i.p.) injection and bath infection. Correlations of msa gene mRNA concentrations with culturable cell concentrations (as colony forming units [CFU]), determined by drop-plate culture method on selective kidney disease medium (SKDM) agar through a $12 \mathrm{wk}$ incubation time, and msa gene DNA concentrations by realtime PCR assay were examined. Furthermore, ovarian fluid samples from wild chum salmon adults with no clinical signs of disease were collected from 8 rivers and from clinically infected kokanee $O$. nerka and masu salmon $O$. masou that were reared in 1 and 2 hatcheries, respectively (total of 414 samples). All samples were examined by nested PCR assay. Then, positive samples were examined by real-time PCR assays for mRNA and DNA; mRNA was detectable at 8 log units $\left(5.0 \times 10^{1}\right.$ to $5.0 \times 10^{9}$ copies $\left.\mu^{-1}\right)$ with high correlation $\left(\mathrm{R}^{2}=0.999\right)$. The mRNA concentration correlated with CFU in kidney tissue from fish infected by i.p. injection $\left(R^{2}=0.924\right)$, by bath infection $\left(R^{2}=0.502\right)$ and in culture $\left(\mathrm{R}^{2}=0.888\right)$. $R$. salmoninarum was detected and quantified by real-time PCR assay for mRNA in ovarian fluid samples in both subclinically infected chum salmon adults and clinically infected kokanee and masu salmon adults; detection rates ranged from 0 to $44.4 \%$ and concentrations ranged from $9.7 \times 10^{2}$ to $5.6 \times 10^{5}$ copies $\mu^{-1}$. These results indicate that real-time PCR assay for the mRNA is a rapid, sensitive and reliable method to detect and quantify the viability of $R$. salmoninarum in kidney and ovarian fluid samples of salmonid fishes with both clinical and subclinical infection of the pathogen.
\end{abstract}

KEY WORDS: Real-time PCR $\cdot$ msa gene mRNA $\cdot$ Renibacterium salmoninarum $\cdot$ Bacterial kidney disease $\cdot$ Viability $\cdot$ Chum salmon

Resale or republication not permitted without written consent of the publisher

\section{INTRODUCTION}

Bacterial kidney disease (BKD) caused by Renibacterium salmoninarum is one of the most important diseases affecting wild and cultured salmonid fishes worldwide (Fryer \& Sanders 1981, Evenden et al. 1993). Among salmonid fish species cultivated in Japan, chum salmon Oncorhynchus keta is the most abundant; more than 2 billion fry are reared in hatcheries and released into rivers annually. The harvest reaches approximately 60 million adults in Japanese coastal waters. Chum salmon are susceptible to infection by $R$. salmoninarum experimentally, although the incidence of BKD has not been reported (Kimura et al. 1987, Sakai et al. 1991). Other salmonid fish species cultivated in Japan, including masu salmon $O$. masou and kokanee O. nerka, are also susceptible to infection by $R$. salmoninarum, and the disease has been reported in hatcheries (Sakai et al. 1986, 1991, Kimura et al. 1987). 
Control of the disease requires a rapid, sensitive and quantitative method for detection of culturable Renibacteriium salmoninarum or estimation of the viability of $R$. salmoninarum in clinically and subclinically infected fish. To screen for infected fish, the fluorescent antibody technique (FAT) (Evelyn et al. 1981, Armstrong et al. 1989, Cvitanich 1994), membrane filtration-fluorescent antibody technique (MF-FAT) (Elliott \& Barila 1987), enzyme-linked immunosorbent assay (ELISA) (Turuga et al. 1987, Pascho \& Mulcahy 1987, Pascho et al. 1991, Rockey et al. 1991, Gudmundsdóttir et al. 1993, Olea et al. 1993), Western blot (WB) (Griffiths et al. 1991), electroimmunotransfer blot (EITB) (Olivier et al. 1992), coagglutination assay (Kimura \& Yoshimizu 1981), PCR assay (Miriam et al. 1997, Pascho et al. 1998) and reverse transcription (RT) PCR assay (Cook \& Lynch 1999) have been performed. Real-time PCR for $R$. salmoninarum DNA has also been reported by several workers (Powell et al. 2005, Chase et al. 2006, Rhodes et al. 2006). Among them, the FAT, WB, EITB, coagglutination, PCR, and RT-PCR assays are not quantitative. In ELISA and MF-FAT assays the quantitative correlation between culturable or viable cells and the measurement values is unclear. Culture on selective kidney disease medium (SKDM) (Austin et al. 1983) is more relevant and sensitive for the detection of culturable cells (Olivier et al. 1992, Lovely et al. 1994, Griffiths et al. 1996), but long incubation times (12 to $19 \mathrm{wk}$ ) are required to detect macroscopic colonies (Benediktsdóttir et al. 1991). This makes the culture technique less practical for BKD diagnostic and screening purposes (Gudmundsdóttir et al. 1993).

Recently, Powell et al. (2005) reported quantification of msa gene (Chien et al. 1992) mRNA in the range of $4.8 \times 10^{1}$ to $4.8 \times 10^{7}$ copies in cultured Renibacterium salmoninarum cells by real-time RT-PCR. Quantitative assays of msa gene mRNA using real-time PCR are expected to indicate the viability of $R$. salmoninarum cells in infected fish for 4 reasons. First, the specificity of the msa gene has been confirmed by PCR assay (Brown et al. 1995, McIntosh et al. 1996, Miriam et al. 1997, Chase \& Pascho 1998) and RT-PCR assay (Cook \& Lynch 1999). Second, bacterial mRNA has a short half-life, measured in minutes (von Gabain et al. 1983, Belasco et al. 1986, Arraiano et al. 1988, Belasco 1993, Alifano et al. 1994, O'Hara et al. 1995, Kushner 1996) due to rapid degradation by the well-organized RNA decay machinery (Rauhut \& Klug 1999, Steege 2000); thus, its detection decreases quickly with the loss of viability of bacteria (Sheridan et al. 1998). Third, expression of the msa gene is constitutive (Grayson et al. 2002). Finally, the nucleotide sequence of the gene might be conserved among strains because $R$. salmoninarum strains isolated from a wide range of hosts and diverse geographic locations have been similar as determined by serological (Wiens \& Kaattari 1989), biochemical (Starliper 1996) and genetic analyses (Grayson et al. 1999).

The purpose of this study were to: (1) develop rapid, sensitive and quantitative methods for detection of $\mathrm{msa}$ gene mRNA of Renibacterium salmoninarum in kidney tissue and ovarian fluid of clinically and subclinically infected fish; (2) elucidate the correlation of msa gene mRNA concentration with culturable cell concentration and msa gene DNA concentration in chum salmon to determine whether quantitative assays for the mRNA could provide an alternative to culturing to assess the viability of $R$. salmoninarum cells; (3) develop a method to screen for viable $R$. salmoninarum cells in large numbers of ovarian fluid samples in salmonid fish broodstock to prevent vertical transmission of the pathogen; and (4) examine whether quantification of msa gene DNA reflects the viability of $R$. salmoninarum cells.

\section{MATERIALS AND METHODS}

Bacterial strains and culture. The Renibacterium salmoninarum strain Rs-3 used in this study was isolated using KDM-2 agar (Evelyn 1977) from a chum salmon juvenile (120 g) during an outbreak at a wet laboratory at the headquarters of the Hokkaido Fish Hatchery, Eniwa, Hokkaido, Japan in July 2004 and subcultured on KDM2 agar at $15^{\circ} \mathrm{C}$. Stock culture was stored at $-80^{\circ} \mathrm{C}$ in KDM-2 broth supplemented with $15 \%$ glycerol. Working cultures were grown on KDM-2 agar at $15^{\circ} \mathrm{C}$. Samples of bacterial cultures, kidney tissues and ovarian fluid were cultured at $15^{\circ} \mathrm{C}$ on SKDM agar (Austin et al. 1983) immediately after collection as described below. Another 7 strains of $R$. salmoninarum, Rs-1, Rs-2, Rs-4, Rs-5, Rs-6, Rs-7 and Rs-8, were identified using nested PCR assay for msa gene described below and cultured on KDM-2 agar and in SKDM broth at $15^{\circ} \mathrm{C}$. Five strains of Flavobacterium psychrophilum, Fp-A, Fp-B, Fp-C, Fp$\mathrm{D}$, and Fp-E, were identified by PCR targeting 16S rDNA (Toyama et al. 1994) and gyrB gene (Izumi \& Wakabayashi 2000) and cultured on modified Cytophaga agar (Wakabayashi \& Egusa 1974) at $15^{\circ} \mathrm{C}$. Those strains were isolated in salmonid fish with clinical or subclinical infection including chum salmon, masu salmon, and coho salmon Oncorhynchus kisutch, kokanee and rainbow trout O. mykiss in Hokkaido, Japan. Aeromonas salmonicida ATCC14174 and NCMB1102, A. hydrophila NCMB86, Vibrio anguillarum NCMB828 and Pseudomonas fluorescens NCMB129 were cultured on Bacto $^{\mathrm{TM}}$ nutrient agar (Becton Dickinson) at $20^{\circ} \mathrm{C}$. Bacillus subtilis ATCC6633, B. cereus ATCC1178 and Micrococcus luteus ATCC9341 were cultured on Bacto ${ }^{\mathrm{TM}}$ nutrient agar at $37^{\circ} \mathrm{C}$. Escherichia coli MV1184 and 
JM109 were purchased from a manufacturer (Takara Bio) and cultured on LB agar (tryptone $1 \%$, yeast extract $0.5 \%, \mathrm{NaCl} 0.5 \%$, agar $1.5 \%, \mathrm{pH} 7.2$ ) at $37^{\circ} \mathrm{C}$.

Fish. Approximately 5000 fertilized chum salmon eggs were transferred from the Dohoku branch of the Hokkaido Fish Hatchery to a wet laboratory at the headquarters. After hatching the fish were reared in 601 tanks supplied with well water at $10^{\circ} \mathrm{C}$ at a constant flow rate of $1.51 \mathrm{~min}^{-1}$ and fed a commercial dry pellet at $2 \%$ body weight daily until use. Sixty fish (mean weight, $0.9 \mathrm{~g}$ ) were collected randomly and kidney tissue samples were spread on trypticase soy agar (TSA; Becton Dickinson), a medium that does not support the growth of Renibacterium salmoninarum, and SKDM agar, and subjected to nested PCR assay, realtime PCR assay for msa gene mRNA and msa gene DNA as described below and the Gram stain reaction; all samples were negative for the 6 assays and, thus, the fish were determined to be free of $R$. salmoninarum.

Detection and quantification of culturable cells. The drop-plate culture method (Evelyn 1977) was performed on bacterial culture, kidney tissue and ovarian fluid samples. Kidney tissue samples were aseptically removed from the sample fish, weighed and homogenized with 9 volumes of a mixture of cold $0.1 \%$ peptone and $0.85 \% \mathrm{NaCl}$ (i.e. peptone-salt, PS) (Evelyn et al. 1981). The bacterial culture, kidney-tissue homogenate and ovarian fluid samples were serially diluted 10 -fold to $10^{-6}$ with cold PS and 3 separate $20 \mu$ drops per dilution were drop-plated onto SKDM agar and TSA and incubated at $15^{\circ} \mathrm{C}$ for $12 \mathrm{wk}$. Colony formation was examined weekly for culturable cell numbers (as colony-forming units [CFU]). Renibacterium salmoninarum was identified by the Gram stain reaction, nested PCR assay on typical colonies from SKDM agar and by the lack of growth on TSA.

Preparation of Renibacterium salmoninarum in bacterial culture. An aliquot of the glycerol stock of Renibacterium salmoninarum strain Rs-3 was cultured while shaking in SKDM broth for $7 \mathrm{~d}$ at $15^{\circ} \mathrm{C}$. A $1 \mathrm{ml}$ aliquot of the culture was added to 11 of SKDM broth and cultured while shaking for $34 \mathrm{~d}$ at $15^{\circ} \mathrm{C}$. At 2, 6, 10, 14, 23, 28 and $34 \mathrm{~d}, 1 \mathrm{ml}$ aliquots were collected for bacterial culture, real-time PCR assay for msa gene mRNA and real-time PCR assay for msa gene DNA in the manner described below.

Experimental infections. Two types of experimental infections were performed: intraperitoneal (i.p.) injection and bath infection. Renibacterium salmoninarum strain Rs-3 was subcultured in KDM-2 broth at $15^{\circ} \mathrm{C}$ for $7 \mathrm{~d}$. Then the bacterial solution was washed twice with cold PS. The bacterial suspension contained $2.6 \times$ $10^{8} \mathrm{CFU} \mathrm{m}{ }^{-1}, 1.7 \times 10^{9} \mathrm{msa}$ gene mRNA copies $\mathrm{ml}^{-1}$, or $3.6 \times 10^{8} \mathrm{msa}$ gene DNA copies $\mathrm{ml}^{-1}$. Six groups of
50 chum salmon fry (mean weight, $0.96 \mathrm{~g}$ ) were placed in separate 601 tanks. Fish in 5 groups were injected i.p. with $0.1 \mathrm{ml}$ of the bacterial solution and reared for $43 \mathrm{~d}$ after infection. One of the 5 groups was observed for cumulative mortality. Another group was injected i.p. with cold PS and used as an uninfected control. The fish were reared at $10^{\circ} \mathrm{C}$ in the manner described above. At 1, 2, 4 and 6 wk after infection kidney tissue samples were collected from 15 live fish chosen at random; 5 samples were stored for 2 to $3 \mathrm{wk}$ at $-80^{\circ} \mathrm{C}$ for real-time PCR assay for mRNA, 5 were stored for 2 to $3 \mathrm{wk}$ at $-80^{\circ} \mathrm{C}$ for real-time PCR assay for DNA and the other 5 samples were used immediately for bacterial culture. Fifteen of the randomly collected dead fish were tested with the same methodology as described above.

Bath infection was performed because the rapid progress of the infection in i.p. injected fish was clearly not representative of the natural disease course. For bath infection, 5 groups of 100 chum salmon fry (mean weight, $1.64 \mathrm{~g}$ ) were placed in separate $60 \mathrm{l}$ tanks that contained 201 still (i.e. no flow through) well water with aeration. Two liters of bacterial culture were prepared and washed twice with cold PS. A 0.51 aliquot of the bacterial solution was added to each of 4 tanks and kept for $1 \mathrm{~h}$ at $10^{\circ} \mathrm{C}$ with aeration in still water. The bacterial concentration in the 201 well water at bath infection was $1.0 \times 10^{7} \mathrm{CFU} \mathrm{ml}^{-1}, 1.9 \times 10^{7} \mathrm{msa}$ gene mRNA copies $\mathrm{ml}^{-1}$, or $5.0 \times 10^{6} \mathrm{msa}$ gene DNA copies $\mathrm{ml}^{-1}$. One group (100 fry) was observed for determination of cumulative mortality and the 3 other groups were examined by the assays. One-half liter of cold PS was added to the remaining tank, which was used as an uninfected control. Fish were reared for $18 \mathrm{wk}$ at $10^{\circ} \mathrm{C}$. At $1,2,4,6,8,10,14$ and $18 \mathrm{wk}$ after infection kidney tissue samples were collected from 15 live fish and treated as above.

Collection of ovarian fluid. Wild chum salmon adult females were collected from 8 rivers and reared in 8 hatcheries (Hatcheries D to K) for a few days. Individual ovarian fluid samples (approximately $1 \mathrm{ml}$ per fish) were collected from 30 randomly selected chum salmon adult females from each of the 8 hatcheries where thus far BKD had not been reported. For comparison ovarian fluid samples of 54 kokanee adults reared at Hatchery $\mathrm{A}$ and 60 masu salmon adults reared at each of Hatcheries B and $C$, were also collected. In Hatcheries A, B and C, BKD occurred in adults; daily mortalities, identified by typical granulomatous lesions in the kidney and by the Gram stain reaction of the lesion smears, were 0.16 to $1.09 \%, 0.01$ to $0.13 \%$, and 0.02 to $0.04 \%$ in Hatcheries $\mathrm{A}, \mathrm{B}$, and C, respectively. Individual samples were divided into $50 \mu$ aliquots and treated as described above; the samples were stored for 2 to $3 \mathrm{~d}$ at $4^{\circ} \mathrm{C}$ before examination. Bacterial culture and nested PCR assays were con- 
ducted for each sample. Then the nested PCR positive samples were further used for real-time PCR assay for msa gene mRNA and real-time PCR assay for msa gene DNA.

Cloning of msa gene. Two identical genes encoding MSA (also designated p57), msa1 and msa2, are present in all strains examined thus far (O'Farrell \& Strom 1999). A third gene, msa3, is present in some strains (Rhodes et al. 2004). The nucleotide sequence of the entire open reading frame (ORF) is the same in all 3 genes. To clone the ORF of the msa gene, the complete ORF of msa1 (O'Farrell \& Strom1999) was amplified from Renibacterium salmoninarum Rs-3 genomic DNA by PCR using forward primer MSA\#1D-For and reverse primer MSA\#1B-Rev (Table 1, Wiens et al. 2002). PCR amplification was performed using an ABI 2400 PCR thermal cycler (Applied Biosystems). PCR was performed in a $50 \mu$ reaction mixture containing $1 \mu \mathrm{l}$ of DNA sample, $50 \mathrm{mM}$ Tris- $\mathrm{HCl}(\mathrm{pH} 9.0), 10 \mathrm{mM}$ $\mathrm{KCl}, 0.1 \%$ Triton-X ${ }^{\mathrm{TM}} 100,1.5 \mathrm{mM} \mathrm{MgCl}_{2}, 0.2 \mathrm{mM}$ $\mathrm{dNTP}, 0.2 \mu \mathrm{M}$ of each primer and 1.25 units Taq DNA polymerase (Promega). Cycling conditions were preheated at $95^{\circ} \mathrm{C}$ for $2 \mathrm{~min}$, followed by 35 cycles of denaturation at $95^{\circ} \mathrm{C}$ for $30 \mathrm{~s}$, annealing for $1 \mathrm{~min}$ at $55^{\circ} \mathrm{C}$ and extension at $72^{\circ} \mathrm{C}$ for $2 \mathrm{~min}$, and one additional extension cycle at $72^{\circ} \mathrm{C}$ for $5 \mathrm{~min}$. Aliquots of PCR products $(15 \mu \mathrm{l})$ were electrophoresed on a $2 \%$ agarose gel containing ethidium bromide at $50 \mu \mathrm{g} \mathrm{ml}^{-1}$ and purified by a Band prep $^{\mathrm{TM}}$ Kit (GE Healthcare Biosciences), and then ligated into a cloning vector pGEM-T Easy ${ }^{\mathrm{TM}}$ (Promega) to form a recombinant plasmid pGEM-T Easy/msa1 ORF and transformed into Escherichia coli MV1184. PCR products of 1379-bp were identified by DNA sequencing with a DYEnamic ET ${ }^{\mathrm{TM}}$ terminator Kit (GE Healthcare Biosciences) using an ABI 370 PRISM $^{\text {TM }}$ automated DNA sequencer (Applied Biosystems).

In vitro transcription of standards. The recombinant plasmid pGEM-T Easy/msa1 ORF was linearized with the enzyme $S p h$ I and purified with a SepaGene ${ }^{\mathrm{TM}}$ Kit (Sanko Jyunyaku). The RNA transcripts were produced using a MEGAscript ${ }^{\mathrm{TM}}$ SP6 Kit (Ambion) by priming transcription of the SP6 polymerase-priming site. Transcripts were run on formaldehyde/MOPS gels to confirm the presence of a single band of the correct size. The transcripts were purified with a MEGAclean $^{\mathrm{TM}}$ kit (Ambion), and the absence of plasmid DNA in the aliquot was confirmed by nested PCR. RNA yields and purity of the transcripts were determined spectrophotometrically by measuring $260 \mathrm{~nm} / 280 \mathrm{~nm}$ absorbance ratios. The concentration of the transcripts was calculated by the molecular weight and Avogádro number, serially diluted 10-fold in Milli-Q ${ }^{\mathrm{TM}}$ (Millipore) water (nanopure water) at 5.0 to $5.0 \times 10^{9} \mathrm{\mu l}^{-1}$, reverse-transcribed and used as standards of real-time PCR assay for the mRNA described below.

cDNA synthesis. cDNA synthesis of standards and unknown samples was conducted using TaqMan ${ }^{\mathrm{TM}}$ reverse transcription reagents (Applied Biosystems). The reaction mixture contained $5 \mu \mathrm{l}$ of $10 \times \mathrm{RT}$ buffer (500 mM KCl, 100 mM Tris- $\mathrm{HCl}_{1} \mathrm{pH}$ 8.3), $5.5 \mathrm{mM}$ $\mathrm{MgCl}_{2}, 0.4 \mu \mathrm{M}$ dNTP, 20 units RNase inhibitor, $2.5 \mu \mathrm{M}$ random hexamer primer, 62.5 units Multiscribe ${ }^{\mathrm{TM}}$ RTase (Applied Biosystems) and $10 \mu \mathrm{l}$ of RNA in a $50 \mu \mathrm{l}$ reaction solution. The reaction solution was incubated at $25^{\circ} \mathrm{C}$ for $10 \mathrm{~min}$, at $37^{\circ} \mathrm{C}$ for $60 \mathrm{~min}$, at $95^{\circ} \mathrm{C}$ for $5 \mathrm{~min}$, held at $4^{\circ} \mathrm{C}$ and stored at $-80^{\circ} \mathrm{C}$. cDNA samples of the standard were divided into $10 \mu \mathrm{l}$ aliquots.

Total RNA extraction of unknown samples. Total RNA was extracted from bacterial cultures, kidney tissue samples and ovarian fluid samples using an RNAqueous $^{\mathrm{TM}}$ Kit (Ambion). Briefly, $1 \mathrm{ml}$ of bacterial culture sample was centrifuged at $10000 \times \mathrm{g}$ for $5 \mathrm{~min}$ at $4^{\circ} \mathrm{C}$. Supernatants were discarded, $100 \mu \mathrm{l}$ of RNA storage solution (RNAlater ${ }^{\mathrm{TM}}$, Ambion) was added to the pelleted bacterial cells and they were stored at $4^{\circ} \mathrm{C}$ for $24 \mathrm{~h}$. An approximately $50 \mathrm{mg}$ sample of kidney tissue per fish was collected aseptically, mixed

Table 1. Primers and probe used for quantification of viable Renibacterium salmoninarum

\begin{tabular}{|llccc|}
\hline Name & Sequence & Position $^{\mathrm{a}}$ & Orientation & Source \\
\hline MSA\#1D-For & 5'-gTC TCC gCT CgT TgC AgA gC-3' & $169-188$ & Forward & Wiens et al. (2002) \\
MSA\#1B-Rev & 5'-Cgg CgT TgC CgT CTT ACC-3' & $2066-2083$ & Reverse & Wiens et al. (2002) \\
UP1 & 5'-Atg TCg CAA ggT gAA ggg-3' & $347-364$ & Forward & Cook \& Lynch (1999) \\
LP3 & 5'-TTA CCC gAT CCA gTT CCC-3' & $1709-1727$ & Reverse & Cook \& Lynch (1999) \\
FL7 & 5'-CgC Agg Agg ACC AgT TgC Ag-3' & $472-491$ & Forward & Miriam et al. (1997) \\
RL11 & 5'-ggA gAC TTg CgA TgC gCC-3' & $803-820$ & Reverse & Miriam et al. (1997) \\
1177F & 5'-CCC AgA TAT CCA TgC ACC AgAT-3' & $1249-1270$ & Forward & This study \\
1313R & 5'-CAA CTg AAA Cgg AAC Cag CATT-3' & $1364-1385$ & Reverse & This study \\
1231T & 5'-FAM-Tgg CgA CAA CAC gTA-MGB-3' & $1303-1320$ & Forward & This study \\
abased on msa1 gene nucleotide sequence (GenBank accession number AF123890) & \\
'TaqMan probe with a 5'-reporter FAM and a 3'-non-fluorescent quencher plus minor groove binder (MGB) \\
\hline
\end{tabular}


with $100 \mu \mathrm{l}$ of RNAlater ${ }^{\mathrm{TM}}$ and stored at $4^{\circ} \mathrm{C}$ for $24 \mathrm{~h}$. The kidney samples were centrifuged at $3000 \times g$ for $5 \mathrm{~min}$ at $4^{\circ} \mathrm{C}$ and the supernatants were discarded. The samples were then stored at $-80^{\circ} \mathrm{C}$. Aliquots $(50 \mu \mathrm{l})$ of ovarian fluid samples were stored at $-80^{\circ} \mathrm{C}$. The samples of bacterial culture, kidney tissue and ovarian fluid were thawed on ice. One hundred microlitres lysozyme solution containing $1 \mathrm{mg}$ of lysozyme in $10 \mathrm{mM}$ Tris- $\mathrm{HCl}(\mathrm{pH}$ 8.0) and $1 \mathrm{mM}$ EDTA ( $\mathrm{pH}$ 8.0) was added to each sample. Total RNA extraction was conducted according to the manufacturer's instructions. DNA in the samples was digested with DNase-I (Turbo DNA-free ${ }^{\mathrm{TM}}$ Kit, Ambion). Thus, the sample volume was increased 1.2-fold to $60 \mu \mathrm{l}$. Finally, the RNA solution contained extracted total RNA from $20 \mu$ of bacterial culture, $1 \mu$ of ovarian fluid or $1 \mathrm{mg}$ of kidney tissue per $\mu \mathrm{l}$. Then, cDNA synthesis was done as described above.

Real-time PCR assay for msa gene mRNA. To quantify cDNA generated by reverse transcription of RNA, real-time PCR with a TaqMan ${ }^{\mathrm{TM}}$ probe was conducted using an ABI 7500 real-time PCR system (Applied Biosystems). The $50 \mu \mathrm{l}$ reaction mixture contained $25 \mu \mathrm{l}$ of TaqMan $^{\mathrm{TM}}$ universal master mix (no uracil-DNA glycosylase [UNG]), $0.9 \mu \mathrm{M}$ forward primer $1177 \mathrm{~F}, 0.9 \mu \mathrm{M}$ reverse primer $1313 \mathrm{R}, 0.4 \mu \mathrm{M}$ TaqMan ${ }^{\mathrm{TM}}$ probe $1231 \mathrm{~T}$ (Table 1) and $5 \mu \mathrm{l}$ of cDNA. The TaqMan ${ }^{\mathrm{TM}}$ probe consisted of an oligonucleotide with a 5 '-reporter fluorescent dye (FAM ${ }^{\mathrm{TM}}$, 6-carboxyfluorescein) and a 3'-nonfluoresecnt quencher plus minor groove binder (MGB). Primers $1177 \mathrm{~F}$ and $1313 \mathrm{R}$ and a TaqMan ${ }^{\mathrm{TM}}$ probe $1231 \mathrm{~T}$ were designed using software Primer Express ${ }^{\mathrm{TM}}$ ver. 2.0 (Applied Biosystems) based on the nucleotide sequence of the msa1 gene of Renibacterium salmoninarum strain ATCC33209 (GenBank accession number AF123890). Reactions were done in duplicate for each sample. Fifty microlitres of each reaction was added to individual wells of a 96 Microamp $^{\mathrm{TM}}$ optical well plate (Applied Biosystems), sealed and placed into the equipment. The signal amplification $(\Delta R n)$, which is the normalized reporter signal (i.e. reporter signal minus normalized background), was plotted against the PCR cycle number to generate cycle threshold $\left(\mathrm{C}_{\mathrm{T}}\right)$ values. The $C_{T}$ values, which are defined as the PCR cycle number at which an increase in reporter fluorescence above baseline is first detected, were plotted against the log concentration of the calculated copy number of the RNA to give standard curves by linear regression. Variability in the reaction was measured as a square regression coefficient $\left(R^{2}\right)$ after the linear regression describing the relationship between the calculated concentration (log input template) of standard samples and $\mathrm{C}_{\mathrm{T}}$ values. The amplification efficiency (e) was estimated by the formula $e=10^{1 / s}-1$, where $s$ is the slope. The $e$ value can be defined as $\mathrm{X}_{n}=$
$\mathrm{X}_{0} \times(1+e)^{n}$, where $\mathrm{X}_{n}$ is the number of target molecules, and $n$ is the number of PCR cycles. Thus, when the amplification efficiency becomes $100 \%$, the e value becomes 1.0. The amplification program was 1 cycle of $95^{\circ} \mathrm{C}$ for $10 \mathrm{~min}$ and 45 cycles of $95^{\circ} \mathrm{C}$ for $15 \mathrm{~s}$ and $60^{\circ} \mathrm{C}$ for $1 \mathrm{~min}$. Accumulated data were analyzed using Sequence detector software version 1.2.2 (Applied Biosystems).

DNA extraction. Nucleic acids (DNA and RNA) were extracted from bacterial cells (1 $\mathrm{ml}$ of culture fluid), kidney tissue samples (50 mg) from chum salmon fry and ovarian fluid samples (50 $\mu \mathrm{l}$ ) from kokanee, masu salmon and chum salmon adults using a SepaGene ${ }^{\mathrm{TM}}$ Kit (Sanko Jyunyaku). Briefly, bacterial cultures were centrifuged at $10000 \times g$ for $5 \mathrm{~min}$ at $4^{\circ} \mathrm{C}$, supernatants were discarded and the pellets were washed twice with cold PS. Finally, nucleic acids were dissolved in Milli- $\mathrm{Q}^{\mathrm{TM}}$ water at the concentration of nucleic acids derived from $1 \mathrm{ml}$ of bacterial culture or $1 \mathrm{mg}$ of kidney tissue or $1 \mu$ l of ovarian fluid per $\mu$ l. DNA yield and purity were determined spectrophotometrically by measuring $260 \mathrm{~nm} / 280 \mathrm{~nm}$ absorbance ratios and 100 to $1000 \mathrm{ng} \mathrm{Hl}^{-1}$ concentrations.

Real-time PCR assay for msa gene DNA. For standards, the recombinant plasmid pGEM-T Easy/msa1 ORF described above was amplified in Escherichia coli MV1184 and extracted by a FlexiPrep ${ }^{\mathrm{TM}}$ Kit (GE Healthcare Biosciences). The concentration of the extracted plasmid was calculated, 10-fold serially diluted with Milli-QTM water at 5.0-5.0 $\times 10^{9}$ copies $\mu^{-1}$ and used as a standard.

Specificity of primers and probe for real-time PCR. DNA was extracted from suspensions of 8 Renibacterium salmoninarum strains and each of the other bacterial strains (see text) in PBS (approximately $10^{6}$ to $10^{8} \mathrm{CFU} \mathrm{m}^{-1}$ ) by SepaGene ${ }^{\mathrm{TM}}$ Kit. Ovarian fluid, kidney tissue, gill tissue and skin tissue samples of 5 fish each from kokanee, chum and masu salmon were collected. DNA extracted from those tissue samples were confirmed negative by nested PCR targeting msa gene as described above, which failed to yield a specific 349 bp product. The extracted DNA was used as a template in real-time PCR for msa gene DNA.

Screening of ovarian fluid by nested PCR assay. Ovarian fluid sampled from each fish was divided into 3 aliquots of $100 \mu \mathrm{l}$ each. An aliquot was cultured immediately after collection and other aliquots were stored at $-80^{\circ} \mathrm{C}$ for the assays as described above. To screen large numbers of ovarian fluid samples a nested PCR assay was performed and the positive samples were further examined by real-time PCR assays for the mRNA and DNA. Two sets of primers were used. For the first round PCR, primers UP-1 and LP-3, which were reported by Cook \& Lynch (1999) to amplify the 1379 bp partial msa1 gene, and for second-round PCR, 
primers FL7 and RL11, which were reported by Miriam et al. (1997) to amplify $349 \mathrm{bp}$ (Table 1) were used. The PCR assay was conducted as described above. The annealing temperature was $55^{\circ} \mathrm{C}$ for the first-round PCR and $60^{\circ} \mathrm{C}$ for the second-round PCR. After the first PCR, $1 \mu \mathrm{l}$ of the reaction mixture was added to the nested PCR reaction. A $15 \mu \mathrm{l}$ aliquot of the nested PCR reaction mixture was electrophoresed at $100 \mathrm{~V}$ for $30 \mathrm{~min}$ in $2 \%$ agarose gels containing ethidium bromide at $0.5 \mu \mathrm{g} \mathrm{ml}^{-1}$. An All-Purpose $\mathrm{Hi}-\mathrm{Lo}^{\mathrm{TM}}$ DNA marker (Bionexus, ) was used as a DNA size marker. Milli- $\mathrm{Q}^{\mathrm{TM}}$ water was used as a negative control. The recombinant plasmid pGEM-T Easy/msa1 ORF was used as a positive control.

Sensitivity of nested PCR assay of seeded kidney tissue and ovarian fluid. Renibacterium salmoninarum strain Rs-3 was subcultured in KDM-2 broth at $15^{\circ} \mathrm{C}$ for $1 \mathrm{wk}$. The culturable cell concentration in a culture was determined as described above to be $5.0 \times 10^{8} \mathrm{CFU} \mathrm{m}{ }^{-1}$. The culture was serially diluted 10 fold with PS to $10^{-8}$. Kidney tissue samples were removed from chum salmon female adults in Hatchery $\mathrm{G}$, homogenized and stored at $-80^{\circ} \mathrm{C}$ until use. Ovarian fluid samples of chum salmon in Hatchery G were collected as described above. The kidney tissues and ovarian fluid samples were examined by nested PCR assay and negative samples were used for the assays. Serial dilutions of the bacteria $(100 \mu l)$ were added to $50 \mathrm{mg}$ homogenized kidney tissue or $50 \mu \mathrm{l}$ ovarian fluid, mixed and incubated at $15^{\circ} \mathrm{C}$ for $1 \mathrm{~h}$. Then, DNA was extracted using a SepaGene ${ }^{\mathrm{TM}}$ Kit, dissolved in $50 \mu \mathrm{l}$ water and used to determine the sensitivity of the nested PCR assay.

Correlation analyses. The square regression coefficient $\left(\mathrm{R}^{2}\right)$ after linear regression was used to measure the relationship between the CFU concentration and the msa gene mRNA or msa gene DNA concentration. Linear regression and the square regression coefficient were analyzed using Microsoft Excel 2003 ${ }^{\mathrm{TM}}$ (Microsoft).

\section{RESULTS}

\section{Specificity of primers and probe for real-time PCR assay}

The specificity of the primers $1177 \mathrm{~F}$ and $1313 \mathrm{R}$, and a TaqMan ${ }^{\mathrm{TM}}$ probe $1231 \mathrm{~T}$ was confirmed. Approximately $10^{6}$ to $10^{7}$ copies of msa gene DNA $\mathrm{ul}^{-1}$ were detected from DNA of all 8 Renibacterium salmoninarum strains tested, whereas no copy was detected from DNA of both the other bacterial strain samples including fish pathogens and the fish tissue samples (see 'Materials and methods').

\section{Reverse transcription followed by real-time PCR assay for msa gene mRNA}

The $\Delta \mathrm{Rn}$ of the standards with 10 -fold serial dilutions ranging from $5.0 \times 10^{1}$ to $5.0 \times 10^{9} \mathrm{msa}_{\mathrm{RNA}} \mathrm{ll}^{-1}$ were plotted against PCR cycle numbers (Fig. 1A). $\mathrm{C}_{\mathrm{T}}$ values plotted against the standard samples (log input RNA) gave a straight line (Fig. 1B). The $\mathrm{R}^{2}$ value was 0.999, which showed a high correlation. The slope of the reaction was -3.356 , and the amplification efficiency (e) was 0.907 . The detection limit was $5.0 \times 10^{1}$ copies $\mu^{-1}$, corresponding to $3.0 \times 10^{2}$ copies $\mathrm{mg}^{-1}$ of kidney tissue samples or $\mathrm{ul}^{-1}$ of ovarian fluid samples because samples were diluted 1.2-fold in DNase I-treatment before cDNA synthesis and further diluted 5-fold in cDNA synthesis.

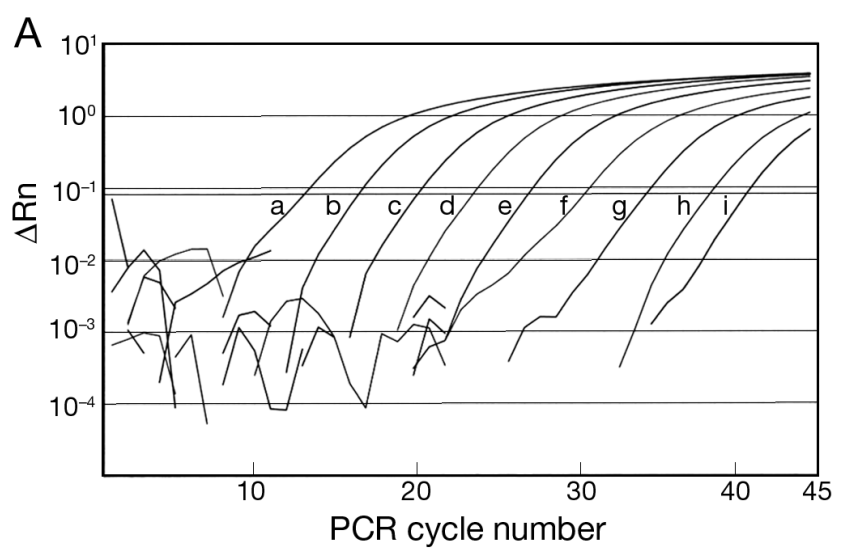

B

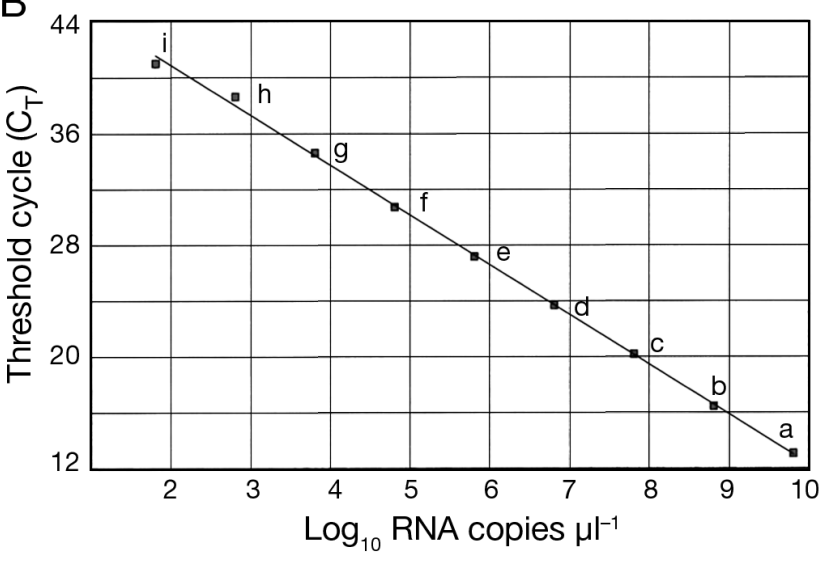

Fig. 1. Reverse transcription followed by real-time PCR assay for msa gene RNA. In vitro-transcribed msa gene RNA with 10fold serial dilutions in Milli- $\mathrm{Q}^{\mathrm{TM}}$ water (nanopure water) was reverse transcribed and used as a standard for real-time PCR assay. (A) Amplification plots of $\Delta \mathrm{Rn}$ versus PCR cycle number. Each plot contains one sample replica. (B) Standard curve of threshold PCR cycle number $\left(\mathrm{C}_{\mathrm{T}}\right)$ versus log concentration of in vitro transcripts followed by reverse transcription (cDNA of msa gene RNA) in each standard. a, $5.0 \times 10^{9} \mathrm{msa}$ RNA copies $\mathrm{Hl}^{-1}$; b, $5.0 \times 10^{8}$; c, $5.0 \times 10^{7} ; \mathrm{d}, 5.0 \times 10^{6} ; \mathrm{e}, 5.0 \times 10^{5} ; \mathrm{f}, 5.0 \times 10^{4}$; g, $5.0 \times 10^{3} ; \mathrm{h}, 5.0 \times 10^{2} ; \mathrm{i}, 5.0 \times 10^{1}$ 


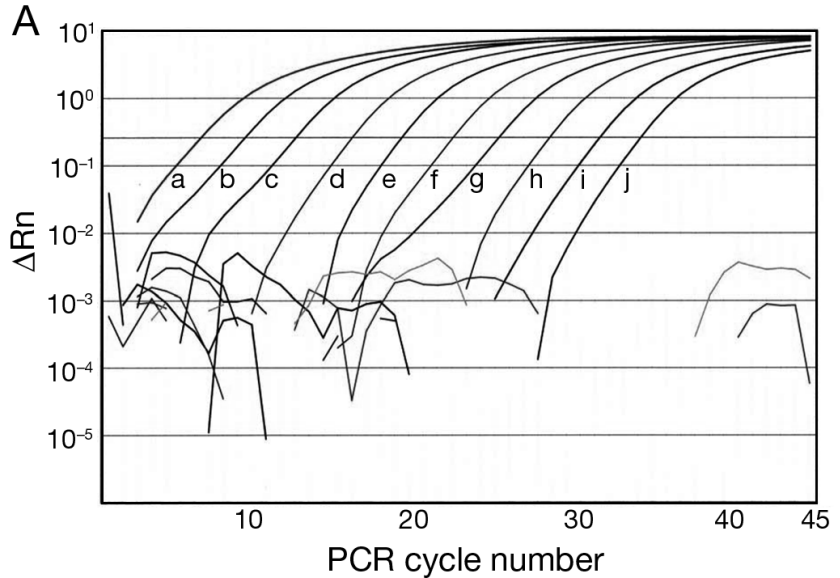

B

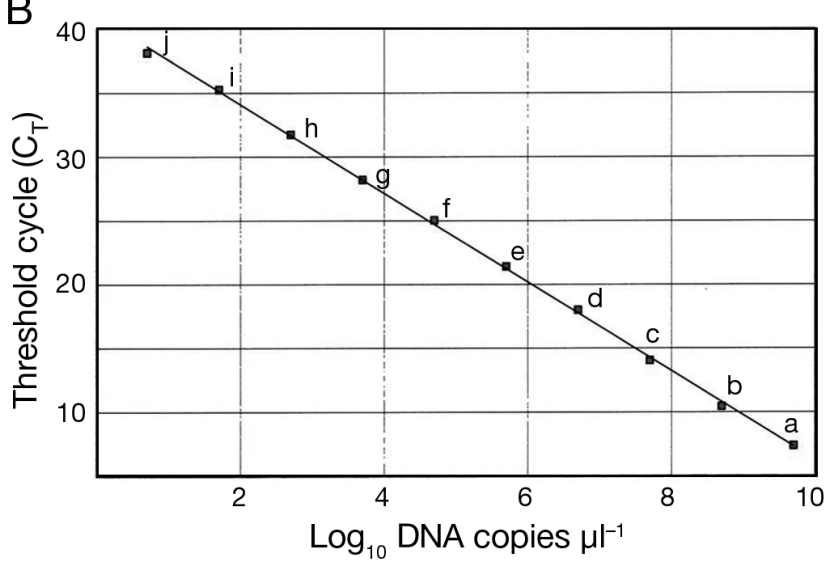

Fig. 2. Real-time PCR assay for msa gene DNA. A recombinant plasmid pGEM-T Easy ${ }^{\mathrm{TM}} / \mathrm{msa} 1 \mathrm{ORF}$, which encodes the complete msa1 gene ORF, was serially diluted 10-fold with Milli$\mathrm{Q}^{\mathrm{TM}}$ water and used as a standard. (A) Amplification plots of $\triangle \mathrm{Rn}$ versus PCR cycle number. Each plot contains one sample replica. (B) Standard curve of threshold PCR cycle number $\left(C_{T}\right)$ versus log concentration of the recombinant plasmid in each standard. a, $5.0 \times 10^{9}$ msa gene DNA copies $\mathrm{\mu l}^{-1} ; \mathrm{b}, 5.0 \times$ $10^{8} ; \mathrm{c}, 5.0 \times 10^{7} ; \mathrm{d}, 5.0 \times 10^{6} ; \mathrm{e}, 5.0 \times 10^{5} ; \mathrm{f}, 5.0 \times 10^{4} ; \mathrm{g}, 5.0 \times 10^{3} ;$ h, $5.0 \times 10^{2} ; \mathrm{i}, 5.0 \times 10^{1} ; \mathrm{j}, 5.0$

\section{Real-time PCR assay for msa gene DNA}

The $\Delta \mathrm{Rn}$ of the standards with 10 -fold serial dilutions ranging from 5.0 to $5.0 \times 10^{9}$ msa gene DNA $\mu l^{-1}$ were plotted against PCR cycle numbers (Fig. 2A). $\mathrm{C}_{\mathrm{T}}$ values plotted against the standard samples (log input DNA) gave a straight line at 5.0 to $5.0 \times 10^{9}$ copies $\mu \mathrm{l}^{-1}$ (Fig. $2 \mathrm{~B})$. The $\mathrm{R}^{2}$ value was 0.999 , which showed a high correlation. The slope of the reaction was -3.474 , and the amplification efficiency was 0.940 . The detection limit was 5 copies $\mu \mathrm{l}^{-1}$, corresponding to 5 copies $\mathrm{mg}^{-1}$ of kidney tissue or $\mu \mathrm{l}^{-1}$ of ovarian fluid. The detection limit of msa gene DNA was 60-fold higher than that of msa gene mRNA.

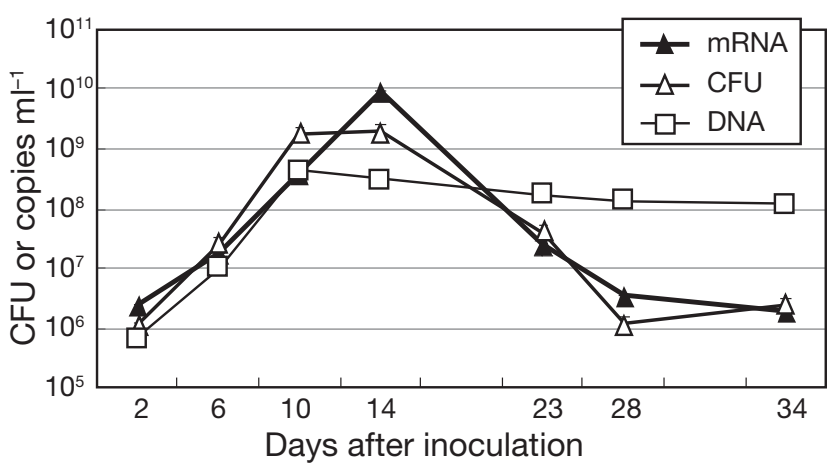

Fig. 3. Comparison between concentrations of msa gene mRNA, msa gene DNA, and culturable Renibacterium salmoninarum cells in bacterial culture. DNA and mRNA were quantified by real-time PCR assay and reverse transcription followed by real-time PCR assay, respectively. The culturable cell concentration was determined by drop-plate culture on SKDM agar plates for $12 \mathrm{wk}$ as CFU. The cells were incubated in SKDM broth while shaking for $34 \mathrm{~d}$ at $15^{\circ} \mathrm{C}$

\section{Bacterial culture}

The msa gene mRNA concentration on Day 0 was $3.3 \times 10^{6} \mathrm{ml}^{-1}$ (mean), increased to $9.2 \times 10^{9} \mathrm{ml}^{-1}$ on Day 14 , and decreased to $2.4 \times 10^{7}, 3.3 \times 10^{6}$, and $1.9 \times$ $10^{6} \mathrm{ml}^{-1}$, respectively, on Days 23, 28, and 34 (Fig. 3). The changes in concentrations of culturable cells showed similar patterns. In contrast, the concentration of msa gene DNA was $1.2 \times 10^{6} \mathrm{ml}^{-1}$ (mean) on Day 0 , increased to $4.2 \times 10^{8}$ on Day 10 and remained constant on Days 14 to 34. The concentration of msa mRNA plotted against culturable cell concentration in samples gave a linear regression. The $\mathrm{R}^{2}$ value was 0.888 and showed a strong relationship between the 2 values. No inhibitory effect on real-time PCR assays was observed in the samples. No contamination was observed on SKDM agar inoculated with the samples.

\section{Infectious experiment I: intraperitoneal injection}

Chum salmon fry (mean weight, $0.96 \mathrm{~g}$ ) began to die $21 \mathrm{~d}$ after infection. The cumulative mortality reached $92 \%$ on Day 43 after infection (Fig. 4A). The cumulative mortality of uninfected controls was $0 \%$. Approximately half of the infected fish showed clinical signs that included darkening of the body color and cessation of feeding. Dead fish showed some or all of the clinical signs including pale gills, swollen abdomens due to ascites, exophthalmos, a pale and swollen kidney, a pale liver, a viscous yellow fluid in the intestine and the presence of culturable Renibacterium salmoninarum cells on SKDM agar plates in kidney tissue. Live fish collected at 4 and $6 \mathrm{wk}$ after infection showed clin- 

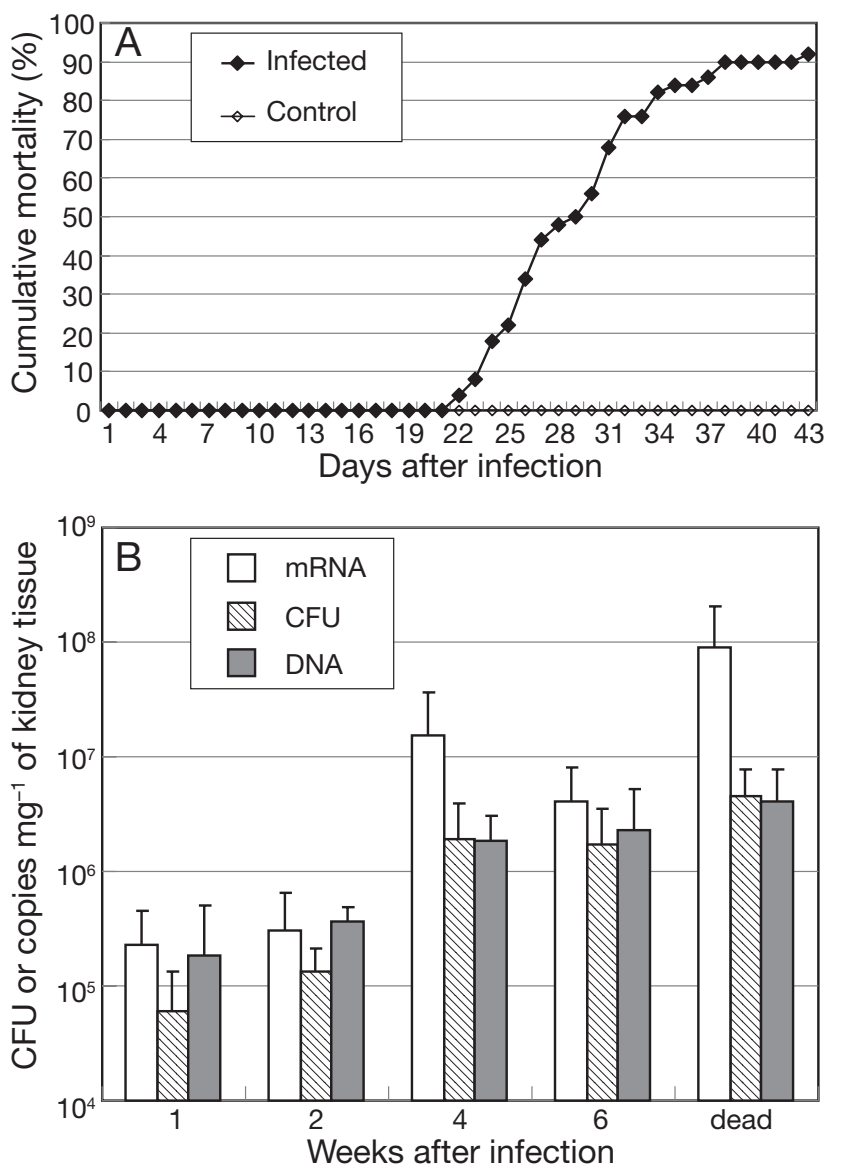

ical signs similar to those of the dead fish. All the smears of the kidney tissue showed Gram-positive diplococcobacilli.

In live fish samples the concentrations of mRNA were $2.3 \times 10^{5}$ and $3.1 \times 10^{5} \mathrm{mg}^{-1}$ of kidney tissue (mean), respectively, at Week 1 and Week 2 after infection and increased to $1.5 \times 10^{7}$ and $4.1 \times 10^{6}$, respectively, at Week 4 and Week 6 (Fig. 4B, Table 2), which were similar to levels in dead fish samples. The culturable cell concentrations and the msa gene DNA concentration showed similar patterns to the mRNA and culturable Renibacterium salmoninarum cell concentrations throughout the experimental period (1 to $6 \mathrm{wk}$ after infection). The prevalence and levels of $R$. salmoninarum determined by the 3 assays were similar throughout the experimental period (Table 2). The beginning of mortality coincided with the increases in mRNA, DNA and culturable cell concentrations (Fig. 4A,B).

Fig. 4. Correlation between msa gene mRNA concentration in chum salmon fry kidney injected i.p. with Renibacterium salmoninarum, msa gene DNA concentration and CFU concentration. The fish were observed for $43 \mathrm{~d}(6 \mathrm{wk})$ after infection. (A) Cumulative mortality (\%) in infected fish ( $\bullet$ ) and uninfected control fish $(\diamond)$. (B) Comparison of the mRNA, gene DNA and CFU concentrations in kidney tissue of infected fish. Live fish were collected 1, 2, 4 and 6 wk after infection. Dead fish were collected during the experimental period. Bars show mean values $+\mathrm{SD}$

Table 2. Culturable cell concentration, msa gene mRNA concentration and msa gene DNA concentration in chum salmon fry kidney tissue experimentally challenged with Renibacterium salmoninarum by i.p. injection and bath infection

\begin{tabular}{|c|c|c|c|c|c|c|c|}
\hline \multirow{2}{*}{$\begin{array}{l}\text { Challenge } \\
\text { method }\end{array}$} & \multirow{2}{*}{$\begin{array}{c}\text { Weeks } \\
\text { after } \\
\text { infection }\end{array}$} & \multirow{2}{*}{$\begin{array}{l}\text { Status of } \\
\text { sample fish }\end{array}$} & \multicolumn{2}{|c|}{ Culturable cells ${ }^{\mathrm{a}} \longleftarrow$} & msa gene mRNA ${ }^{\mathrm{b}}$ & \multicolumn{2}{|c|}{ - msa gene $\mathrm{DNA}^{\mathrm{c}}-$} \\
\hline & & & \multicolumn{2}{|c|}{$\begin{array}{l}\text { CFU mg } \\
\text { of kidney }\end{array}$} & $\begin{array}{l}\text { Copies } \mathrm{mg}^{-1} \text { Prevalence } \\
\text { of kidney }\end{array}$ & \multicolumn{2}{|c|}{$\begin{array}{l}\text { Copies } \mathrm{mg}^{-1} \text { Prevalence }^{\mathrm{e}} \\
\text { of kidney }\end{array}$} \\
\hline \multirow{5}{*}{$\begin{array}{l}\text { Intraperitoneal } \\
\text { injection }\end{array}$} & 1 & Live & $1.5-1.7 \times 10^{5}$ & $5 / 5$ & $3.5 \times 10^{4}-5.3 \times 10^{5} \quad 4 / 5$ & $2.0 \times 10^{3}-7.3 \times 10^{5}$ & $4 / 5$ \\
\hline & 2 & Live & $9.2 \times 10^{3}-2.0 \times 10^{5}$ & $5 / 5$ & $3.0 \times 10^{4}-7.7 \times 10^{5} \quad 4 / 5$ & $2.2 \times 10^{5}-5.1 \times 10^{5}$ & $5 / 5$ \\
\hline & 4 & Live & $2.3 \times 10^{5}-5.0 \times 10^{6}$ & $5 / 5$ & $8.0 \times 10^{5}-5.3 \times 10^{7} \quad 5 / 5$ & $1.7 \times 10^{5}-2.9 \times 10^{6}$ & $5 / 5$ \\
\hline & 6 & Live & $2.5 \times 10^{5}-3.6 \times 10^{6}$ & $5 / 5$ & $2.3 \times 10^{5}-8.5 \times 10^{6} \quad 4 / 5$ & $7.0 \times 10^{3}-6.4 \times 10^{6}$ & $5 / 5$ \\
\hline & - & Dead & $2.0 \times 10^{6}-1.6 \times 10^{7}$ & $5 / 5$ & $1.6 \times 10^{7}-2.9 \times 10^{8} \quad 5 / 5$ & $1.2 \times 10^{5}-1.0 \times 10^{7}$ & $5 / 5$ \\
\hline \multirow[t]{9}{*}{ Bath infection } & 1 & Live & $<0.5$ & $0 / 5$ & $1.4 \times 10^{4}-3.6 \times 0^{4} \quad 2 / 5$ & $<5.0 \times 10^{1}$ & $0 / 5$ \\
\hline & 2 & Live & $0.7-1.2$ & $2 / 5$ & $<3.0 \times 10^{2}$ & $<5.0 \times 10^{1}$ & $0 / 5$ \\
\hline & 4 & Live & $0.8-1.5 \times 10^{1}$ & $4 / 5$ & $8.0 \times 10^{4}$ & 7.1 & $1 / 5$ \\
\hline & 6 & Live & $1.2-7.5$ & $3 / 5$ & $8.7 \times 10^{3}$ & $<5.0 \times 10^{1}$ & $0 / 5$ \\
\hline & 8 & Live & $1.3 \times 10^{1}-2.7 \times 10^{1}$ & $2 / 5$ & $4.1 \times 10^{2}-7.8 \times 10^{2}$ & $8.3 \times 10^{2}$ & $1 / 5$ \\
\hline & 10 & Live & $1.0 \times 10^{1}-6.3 \times 10^{1}$ & $4 / 5$ & $4.6 \times 10^{2}-2.0 \times 10^{3}$ & $<5.0 \times 10^{1}$ & $0 / 5$ \\
\hline & 14 & Live & $1.4 \times 10^{2}-5.7 \times 10^{4}$ & $4 / 5$ & $8.2 \times 10^{2}-1.6 \times 10^{5} \quad 4 / 5$ & $3.5 \times 10^{2}-9.0 \times 10^{4}$ & $4 / 5$ \\
\hline & 18 & Live & $5.3 \times 10^{1}-1.8 \times 10^{7}$ & $5 / 5$ & $8.4 \times 10^{2}-3.3 \times 10^{3} \quad 5 / 5$ & $2.9 \times 10^{2}-4.0 \times 10^{5}$ & $4 / 5$ \\
\hline & - & Dead & $2.5 \times 10^{5}-1.5 \times 10^{8}$ & $5 / 5$ & $2.9 \times 10^{5}-2.6 \times 10^{6} \quad 4 / 5$ & $6.1 \times 10^{3}-2.4 \times 10^{4}$ & $5 / 5$ \\
\hline \multicolumn{8}{|c|}{$\begin{array}{l}{ }^{a} \mathrm{CFU} \text { concentration was determined by drop-plate culture (Evelyn et al. 1977) on SKDM agar (Austin et al. 1983) for } 12 \text { wk. } \\
\text { The detection limit is } 0.5 \mathrm{CFU} \mathrm{mg}{ }^{-1} \text { of kidney tissue }\end{array}$} \\
\hline \multicolumn{8}{|c|}{$\begin{array}{l}{ }^{\mathrm{b}} \mathrm{msa} \text { gene mRNA concentration was determined by reverse transcription followed by real-time PCR assay. The detection limit } \\
\text { is } 3 \times 10^{2} \text { copies } \mathrm{mg}^{-1} \text { of kidney tissue }\end{array}$} \\
\hline \multirow{2}{*}{\multicolumn{8}{|c|}{$\begin{array}{l}{ }^{\mathrm{c}} \mathrm{msa} \text { gene DNA concentration was determined by real-time PCR assay. The detection limit is } 5 \times 10^{1} \mathrm{copies}^{-1} \mathrm{mg}^{-1} \mathrm{kidney} \\
\text { tissue } \\
{ }^{\mathrm{d} F i g u r e s} \text { indicate range of the values of every sample }\end{array}$}} \\
\hline & & & & & & & \\
\hline \multicolumn{8}{|c|}{ ePrevalence indicates number of positive samples per number of samples examined } \\
\hline
\end{tabular}


Lower or no concentration values of DNA, approximately one-tenth of the actual values or lower, were obtained in real-time PCR assay for the DNA, revealing an inhibitory effect by kidney tissue samples (data not shown). Thus, the DNA samples of the kidney tissue were diluted 10-fold with Milli- ${ }^{\mathrm{TM}}$ water and used for the assay, resulting in decrease of the detection limit of the DNA quantification to 50 copies $\mathrm{mg}^{-1}$ of kidney tissue, whereas no inhibitory effect was observed in real-time PCR assay for the mRNA. No contamination was observed in bacterial cultures on SKDM agar.

The concentration of msa mRNA plotted against culturable cell concentration in samples gave a linear regression; the $\mathrm{R}^{2}$ value was 0.924 and highly correlated, whereas the $\mathrm{R}^{2}$ value between culturable cell
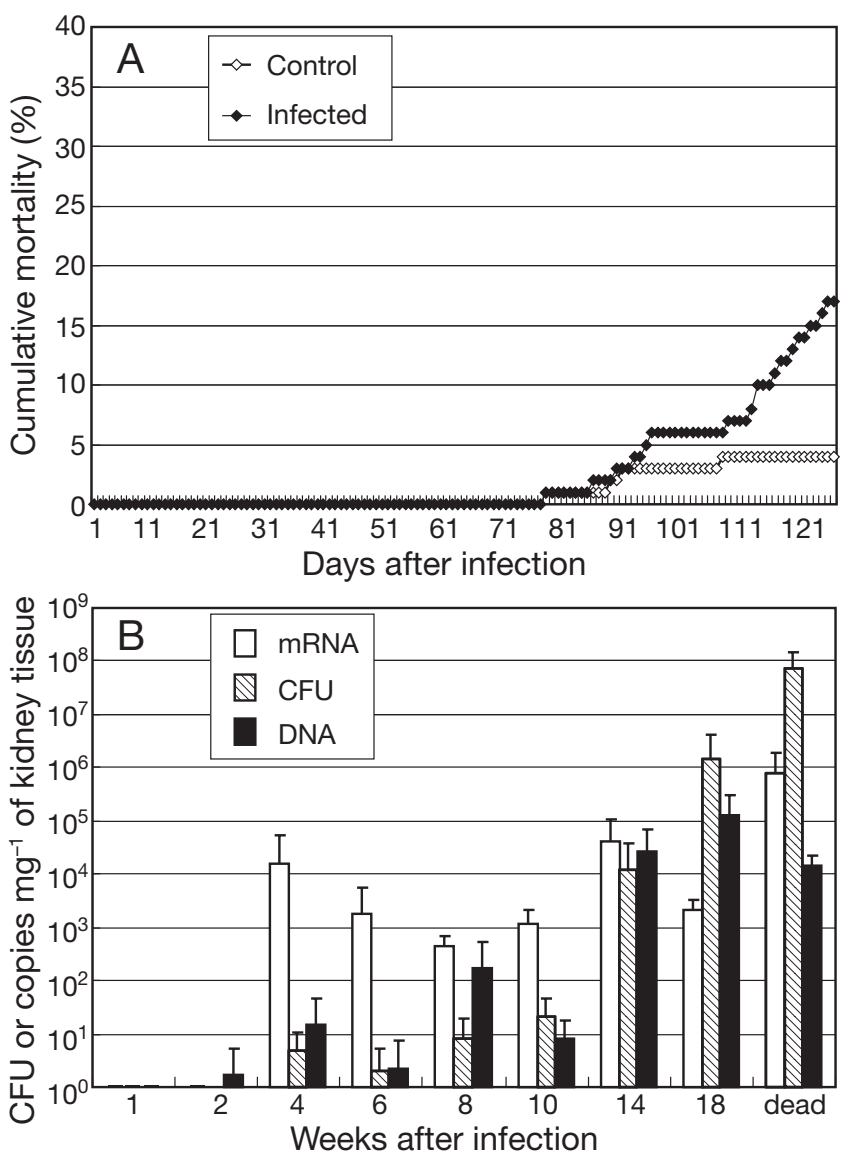

Fig. 5. Correlation of msa gene mRNA concentration in chum salmon fry kidney infected with Renibacterium salmoninarum in bath infection with msa gene DNA and CFU concentrations. The fish were observed for $126 \mathrm{~d}(18 \mathrm{wk})$ after infection. (A) Cumulative mortality (\%) in infected fish and uninfected control fish. (B) Comparison among mRNA, gene DNA and CFU concentrations in infected fish. Live fish were collected $1,2,4,6,8,10,14$ and 18 wk after infection. Dead fish were collected during the experimental period. Bars show mean values $+\mathrm{SD}$ concentration and the DNA concentration was 0.992 and, thus, showed a higher correlation.

\section{Infectious experiment II: bath infection}

Infected chum salmon fry (mean weight, $1.64 \mathrm{~g}$ ) began to die on Day 77 after infection. Deaths continued and the cumulative mortality on Day 127 was $17 \%$ (Fig. 5A). The cumulative mortality of the uninfected control was $4 \%$. Most dead fish (31 of 42 fish collected) and some live fish collected (15 of 120 fish) showed white granulomatous lesions in the kidney. Approximately $90 \%$ of the dead fish showed clinical signs that included darkening of the skin color, pale gills, exophthalmos, a pale liver, a pale and swollen kidney and a yellow viscous fluid in the intestine. Live fish collected 1 to $10 \mathrm{wk}$ after infection showed no clinical signs except for pale gills and darkening of the skin color in approximately $10 \%$ of the fish, whereas those collected 14 and 18 wk after infection showed clinical signs similar to those of the dead fish.

The concentration of msa gene mRNA was higher in live fish collected in the early phase of bath infection (4 to 10 wk after infection) compared with the DNA and culturable cell concentrations at corresponding sampling times (Fig. 5B, Table 2), whereas the DNA and culturable cell concentrations increased gradually 1 to $10 \mathrm{wk}$ after infection to reach the levels similar to those of the dead fish 14 and 18 wk after infection (Fig. $5 \mathrm{~B}$, Table 2 ). In the early phase of infection (1 to $10 \mathrm{wk}$ after infection) the prevalence of Renibacterium salmoninarum determined by the mRNA quantification was higher than that determined by the DNA quantification, particularly in the samples collected during the early phase of bath infection (Table 2), while in the late phase of infection (14 and $18 \mathrm{wk}$ after infection and in dead fish) the prevalence of $R$. salmoninarum determined by the 3 assays was almost the same. The beginning of death coincided with increases in the mRNA, the DNA and CFU concentrations (Fig. 5A,B).

Lower DNA concentrations, approximately onetenth of the actual values obtained in real-time PCR assay, revealed the inhibitory effect of kidney tissue samples (data not shown). Therefore, the DNA samples of the kidney tissue were diluted 10-fold with Milli- $\mathrm{Q}^{\mathrm{TM}}$ water and used for the assay resulting in a decrease in the detection limit to 50 copies $\mathrm{mg}^{-1}$ of kidney tissue, whereas no inhibitory effect was observed in real-time PCR assay for the mRNA. No contamination was observed on SKDM agar inoculated with the samples.

The samples gave a linear regression between the culturable cell and mRNA concentrations; the $\mathrm{R}^{2}$ value 
was 0.502 and showed a weak relationship between the 2 values, whereas the $\mathrm{R}^{2}$ value between the culturable cell and DNA concentrations was 0.813 and showed a higher correlation.

\section{Sensitivity of nested PCR assay for seeded kidney tissue and ovarian fluid samples}

Nested PCR amplification 349 bp products were obtained from DNA extracts of $1.0 \times 10^{1}$ to $1.0 \times 10^{3}$ $\mathrm{CFU} \mathrm{Ll}^{-1}$ of bacterial culture (Fig. $6 \mathrm{~A}$ ), $1.0 \times 10^{1}$ to $1.0 \times$

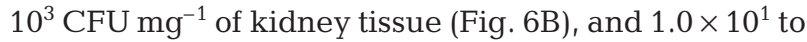
$1.0 \times 10^{3} \mathrm{CFU} \mathrm{ll}^{-1}$ of ovarian fluid (Fig. 6C). No inhibitory effect by the tissue was observed.

\section{Ovarian fluid sample of salmonids}

Ovarian fluid samples collected from chum salmon were 0 to $6.7 \%$ positive in culture. Detection rates (number positive / number examined) were 0 to $30 \%$ in nested PCR assay, 0 to $30 \%$ in real-time PCR assay for mRNA and 6.7 to $30 \%$ in real-time PCR assay for DNA (Table 3, Fig. 7A), whereas prevalence from masu salmon and kokanee was 3.3 to $11 \%$ positive in culture; detection rates were 25 to $44.4 \%$ in nested PCR, 16.7 to $31.5 \%$ in real-time PCR assay for mRNA, and 25 to $44.4 \%$ in real-time PCR assay for DNA. The prevalence of culturable cells was lower than that of DNA and mRNA in all 3 salmonid species. Contamination with various faster growing bacteria was observed on SKDM agar plates inoculated with lower dilutions $\left(10^{0}\right.$ to $10^{-2}$ dilution) of ovarian fluid samples of salmonid fish, in particular chum salmon (Table 3), whereas higher dilutions $\left(10^{-3}\right.$ to $\left.10^{-6}\right)$ produced neither contamination nor Renibacterium salmoninarum colonies.

The concentrations of mRNA and DNA in chum salmon ovarian fluid were $9.7 \times 10^{2}$ to $2.5 \times 10^{4} \mathrm{\mu l}^{-1}$ (mean) and $2.8 \times 10^{2}$ to $1.1 \times 10^{3} \mu^{-1}$ (mean), respectively (Table 3, Fig. 7B). The masu salmon samples showed similar results, whereas the kokanee samples showed higher values.

The $\mathrm{R}^{2}$ value between the mRNA concentration (mean) and detection rate of the mRNA was 0.590 and weakly correlated, while the $\mathrm{R}^{2}$ value between DNA concentration and its detection rate was 0.716 .

\section{DISCUSSION}

In the reverse transcription (RT) followed by realtime PCR assay for msa gene mRNA the quantifiable range was $5.0 \times 10^{1}$ to $5.0 \times 10^{9}$ copies $\mu l^{-1}$ of sample, which corresponds to $3 \times 10^{2}$ to $3 \times 10^{10}$ copies $\mathrm{mg}^{-1}$ of kidney tissue or $\mu^{-1}$ of ovarian fluid. The square
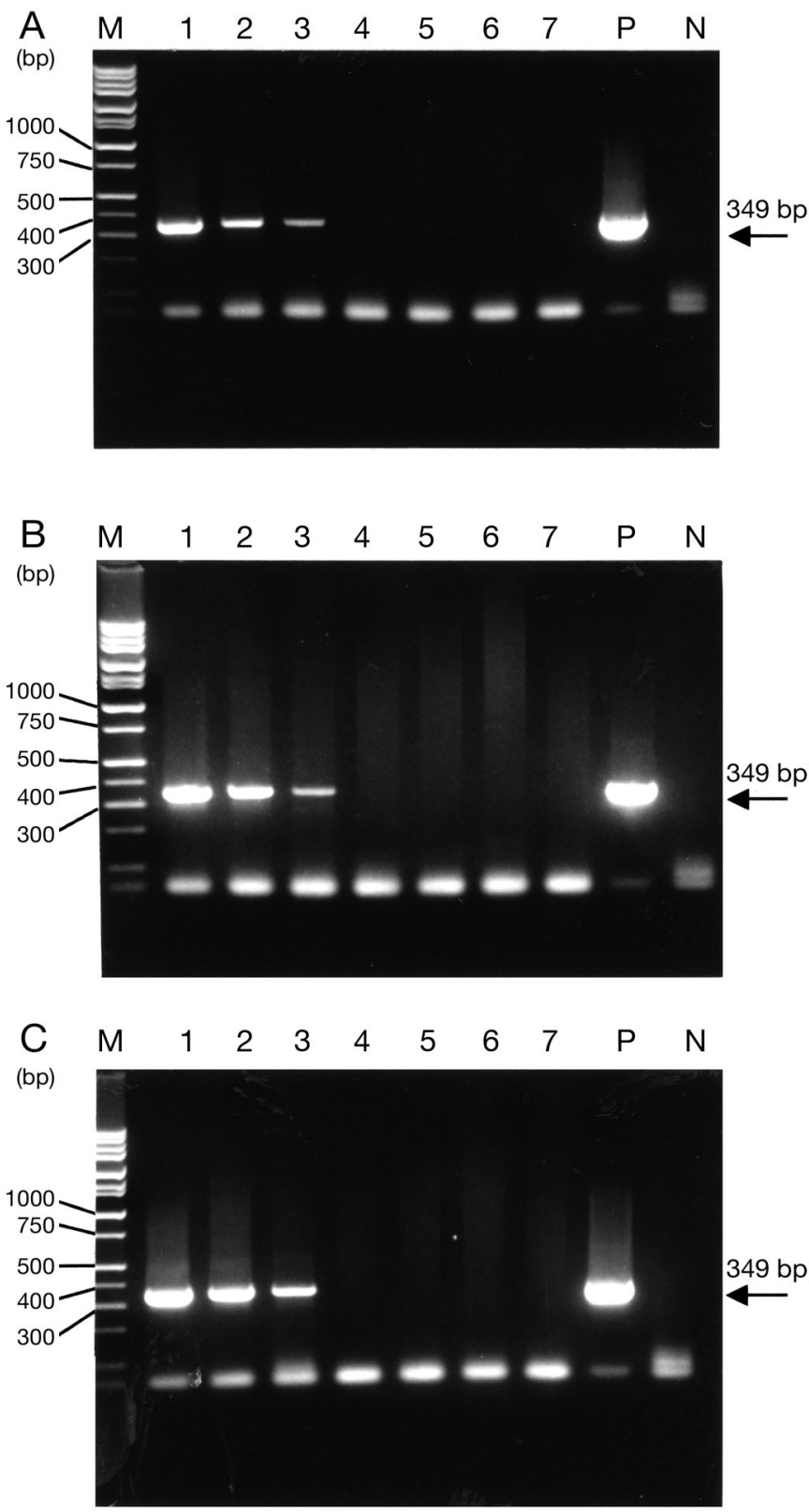

Fig. 6. Sensitivity of nested PCR assay for bacterial culture, seeded kidney tissue homogenate and seeded ovarian fluid samples. PCR amplification products were electrophoresed on $2 \%$ agarose gels containing ethidium bromide at $0.5 \mu \mathrm{g} \mathrm{ml}^{-1}$. (A) Nested PCR products from DNA extract of Renibacterium salmoninarum cells serially diluted 10 -fold in bacterial culture. (B) Nested PCR products from DNA extract of kidney homogenate samples seeded with $R$. salmoninarum cells serially diluted 10-fold. (C) Nested PCR products from DNA extract of ovarian fluid samples seeded with $R$. salmoninarum cells serially diluted 10 -fold. Lane $1,1.0 \times 10^{3} \mathrm{CFU}^{-1} \mathrm{l}^{-1}$; Lane $2,1.0 \times$

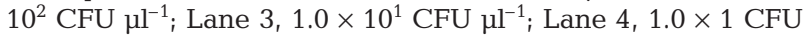
$\mu^{-1}$; Lane 5, $1.0 \times 10^{-1} \mathrm{CFU}^{-1} \mathrm{l}^{-1}$, Lane 6, $1.0 \times 10^{-2} \mathrm{CFU}^{-1}$; Lane 7, unseeded sample; $\mathrm{M}$, DNA marker ( $\mathrm{Hi}-\mathrm{Lo}^{\mathrm{TM}}$ All purpose DNA marker, Bionexus); P, Plasmid pGEM-T Easy ${ }^{\mathrm{TM}}$ / msa1 ORF as a positive control; N, Milli- $\mathrm{Q}^{\mathrm{TM}}$ water (nanopure water) as a negative control. Arrows indicate the position of the $349 \mathrm{bp}$ PCR product 


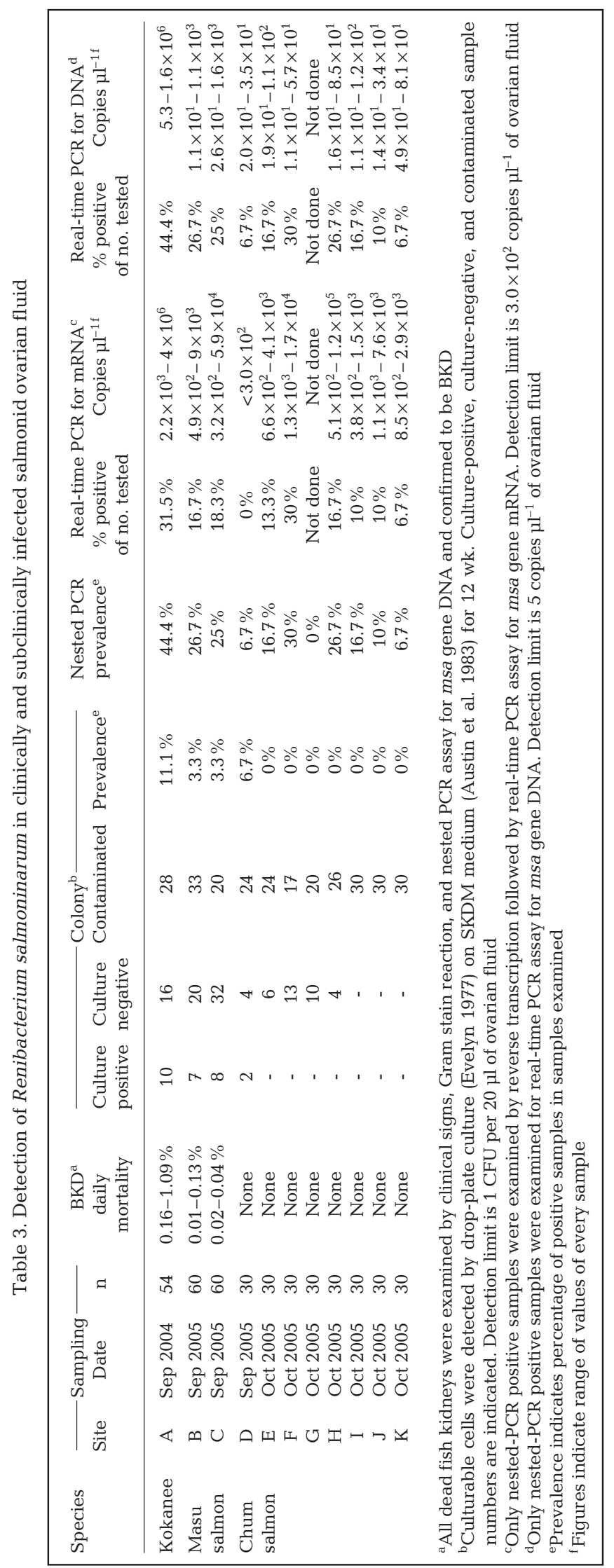

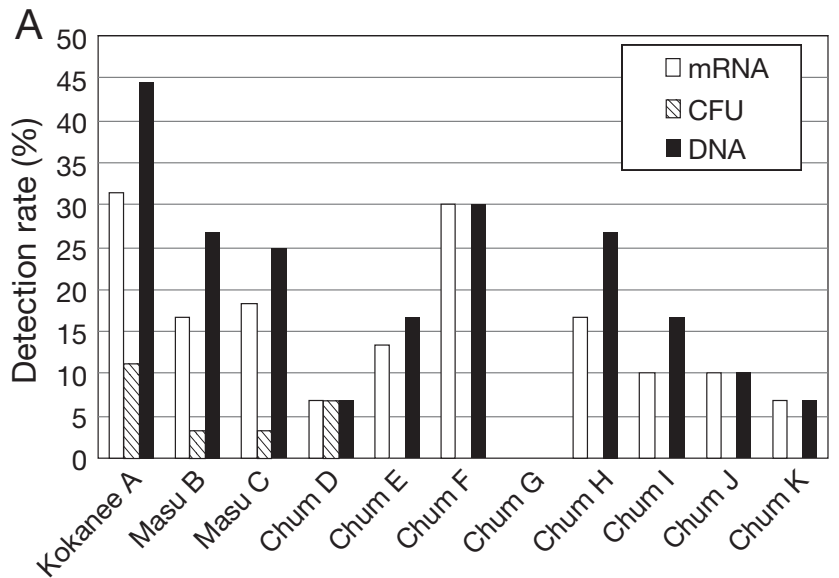

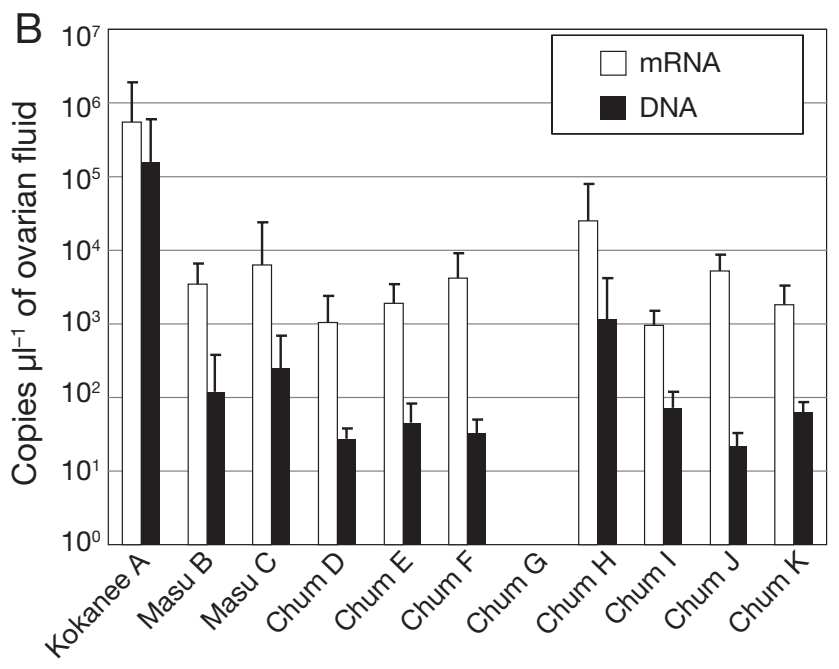

Fig. 7. Detection rate and quantification of msa gene mRNA, CFU, and msa gene DNA in ovarian fluid samples of adult kokanee and masu and chum salmon. (A) Detection rate of CFU, msa gene mRNA and msa gene DNA in ovarian fluid samples from kokanee adults reared at 1 hatchery, masu salmon adults reared at 2 hatcheries and wild chum salmon adults collected from 8 rivers and reared in 8 hatcheries for a few days. CFU, mRNA and DNA were detected, respectively, by drop-plate culture on SKDM agar for $12 \mathrm{wk}$, reverse transcription followed by real-time PCR, and real-time PCR. (B) Quantification of mRNA and DNA in ovarian fluid. Ovarian fluid samples were screened by nested PCR assay and the positive samples were used for real-time PCR assay for DNA and reverse transcription followed by real-time PCR assay for mRNA. Bars show mean values $+\mathrm{SD}$

regression coefficient $\left(\mathrm{R}^{2}\right)$ and amplification efficiency (e) in the standard were 0.999 and 0.904 , respectively. The linearity of the standard curves with a range at $8 \log$ units, high $\mathrm{R}^{2}$ value and high e value confirmed that the assay would be suited for quantitative measurement of msa gene mRNA. The linear relationship and detection limit were higher than those of other reports using a quantitative PCR assay for msa gene mRNA of Renibacterium salmoninarum (Powell et al. 2005). The detection limit of msa gene mRNA in this 
study was one log unit lower than that of msa gene DNA. Thus, the difference is due to the efficiency of reverse transcription in the mRNA quantification, which is approximately $10 \%$. However, in this study total extraction and cDNA synthesis of unknown samples were done under the same conditions and, thus, the reverse-transcription efficiency did not influence the overall pattern of the results.

In bacterial culture and in kidney tissue of chum salmon fry infected by i.p. injection and in the late phase of bath infection (14 and $18 \mathrm{wk}$ after infection), in which fish showed clinical signs and the culturable cell concentration of kidney tissue was more than $10^{4}$ CFU mg ${ }^{-1}$, the msa gene mRNA concentration correlated well with the culturable Renibacterium salmoninarum cell concentration. Moreover, prevalence of mRNA was similar to that of culturable cells. Thus, detection and quantification of msa gene mRNA would reflect the infection status of the fish. While in the early phase of bath infection (1 to $10 \mathrm{wk}$ after infection) in which chum salmon fry showed no clinical signs, higher mRNA concentrations in kidney tissue samples were detected in comparison with the culturable cell concentration $\left(<10^{4} \mathrm{CFU} \mathrm{mg}^{-1}\right.$ of kidney tissue). This resulted in a weaker correlation between the 2 values in bath infection $\left(\mathrm{R}^{2}=0.502\right)$. The higher mRNA concentration and higher detection rates in such fish would reflect the viability of $R$. salmoninarum cells. In kidney tissue of both clinically and subclinically infected fish real-time PCR assay for the mRNA would be rapid (approximately $30 \mathrm{~h}$ compared with $12 \mathrm{wk}$ or more in culture) and accurate, although it would be less sensitive than culture on SKDM agar plates, especially during the early phase of the bath infection.

The ability of quantification of msa gene mRNA by real-time PCR to assess the viability of Renibacterium salmoninarum cells would be supported by the following 4 reasons. First, the primers and Taqman ${ }^{\mathrm{TM}}$ probe used in this study were specific to $R$. salmoninarum. The specificity of the nucleotide sequence of msa gene has been demonstrated by this study and also by PCR assay (Brown et al. 1995, McIntosh et al. 1996, Miriam et al. 1997, Chase \& Pascho 1998) and RT-PCR assay (Cook \& Lynch 1999). Second, compared with bacterial gene DNA and rRNA, mRNA has a short half-life, measured in minutes, and would be a good indicator of cell viability (Arraiano et al. 1988, Belasco 1993, Alifano et al. 1994), although the persistence of mRNA may vary from a few minutes to several hours depending on the environmental conditions and mRNA from different species (Sheridan et al. 1998, McIngvale et al. 2002), and the methods of inactivating treatments and subsequent holding conditions (Jou et al. 1997, Sheridan et al. 1998, Birch et al. 2001). Cook \& Lynch (1999) reported that inactivation of cultured $R$. salmoninarum by rifampicin or erythromycin produced a loss of $m s a$ gene mRNA detection by nested RT-PCR corresponding to a loss of culturable $R$. salmoninarum concentration and that nested RT-PCR identified similar levels of infected fish in subclinical live Atlantic salmon Salmo salar as determined by culture on SKDM agar. Third, msa gene is constitutively expressed (Grayson et al. 2002) and thus, would enable us to detect viable $R$. salmoninarum cells irrespective of the status of the bacteria. Finally, nucleotide sequences of the msa gene ORF might be conserved among strains because the strains isolated from a wide range of hosts and geographic areas have indicated relatively low genetic diversity based on serological (Wiens \& Kaattari 1989), biochemical (Starliper 1996) and genetic data (Grayson et al. 1999). Thus, the primers and TaqMan ${ }^{\mathrm{TM}}$ probe used in this study would be valid to detect and quantify msa gene DNA and msa gene mRNA of $R$. salmoninarum strains isolated in salmonid fish in Hokkaido, Japan.

In ovarian fluid samples from clinically and subclinically infected salmonid broodstock, quantification of msa gene mRNA would be a good indicator of viability of Renibacterium salmoninarum cells. Due to the contamination of SKDM agar with other faster-growing microorganisms the correlation between culturable $R$. salmoninarum and mRNA concentrations in ovarian fluid was unclear. However, the salmonid ovarian fluid samples positive for real-time PCR assay for mRNA might have contained lower concentrations of the culturable cells, which were at most $5.0 \times 10^{1}$ $\mathrm{CFU} \mu \mathrm{l}^{-1}$, corresponding to $1.0 \times 10^{2} \mathrm{msa}$ gene DNA $\mathrm{\mu l}^{-1}$. Contamination was observed only on SKDM agar plates inoculated with $10^{0}$ to $10^{-2}$ dilutions and neither contamination nor $R$. salmoninarum cell colonies were observed in those inoculated with higher dilutions $\left(10^{-3}\right.$ to $\left.10^{-6}\right)$, thus, the detection limit of $10^{-3}$ dilutions was $5 \times 10^{1} \mathrm{CFU}_{\mu \mathrm{l}^{-1}}$. The prevalence and quantification of msa gene DNA and msa gene mRNA support this idea. Viable but nonculturable $R$. salmoninarum cells might contribute to the detection and quantification of mRNA in ovarian fluid samples, although the presence of such cells in $R$. salmoninarum has not been reported thus far. The quantification of mRNA concentration (mean) correlated with the detection rate $\left(R^{2}=0.590\right)$ reflect the viability of $R$. salmoninarum in clinically and subclinically infected broodstock.

Contamination with other faster-growing microorganisms occurred in 28 of 54 samples examined, 33 of 60 , and 20 of 60 , and 17 of 30 to 30 of 30, respectively, in kokanee, masu salmon and chum salmon ovarian fluid samples. Frequencies of contamination differed among the 3 salmonid fish species and, thus, factors related to the differences among the species might 
contribute to this. The cause of the contamination remained unknown and further study would be required.

Because the nested PCR assay is less laborious, timeconsuming and expensive for large numbers of samples (414 samples in this study), the broodstock were screened for msa gene DNA by nested PCR assay. Positive samples were then used for real-time PCR assays for msa gene mRNA and for msa gene DNA. A combination of methods, nested PCR assay and real-time PCR assay for the mRNA, would be advantageous for investigating the mRNA in large numbers of ovarian fluid samples and could be applied to screen large numbers of other tissue samples, including kidney.

In this study detection and quantification of msa gene DNA was conducted to examine its correlation to the viability of Renibacterium salmoninarum cells in clinically and subclinically infected fish. A good correlation was obtained between the msa gene DNA concentration and the culturable cell concentration in kidney tissues of chum salmon fry experimentally challenged by both i.p. injection and bath infection. The $\mathrm{R}^{2}$ values were 0.992 for i.p. injection and 0.813 for bath infection and were higher than the corresponding $\mathrm{R}^{2}$ values between the mRNA concentration and the culturable cell concentration (0.924 and 0.502). Furthermore, the prevalence of DNA in the late phase of bath infection (14 and $18 \mathrm{wk}$ after infection) was similar to that of the culturable cells. The results indicate that under certain conditions quantification of msa gene DNA is a good indicator of the culturable cell concentration in chum salmon. This conclusion is supported by studies on the correlation between quantification of a gene by quantitative PCR assay and viable cell concentration in bifidobacteria in human feces (Requena et al. 2002, Gueimonde et al. 2004), Listeria monocytogenes and L. innocua in food (Nogva et al. 2000, Rodríguez-Lazaró et al. 2004), and Staphylococcus aureus in food (Hein et al. 2001). Furthermore, prevalence of Renibacterium salmoninarum among naturally infected chinook salmon Oncorhynchus tshawytscha population was investigated by real-time PCR assay for the bacterial genome DNA and the assay was reportedly valid (Chase et al. 2006, Rhodes et al. 2006). Those studies also support our results.

On the other hand, a discrepancy between the prevalence of msa gene DNA and that of culturable Renibacterium salmoninarum cells was shown in salmonid kidney tissue in the early phase of bath infection (2 to $10 \mathrm{wk}$ after infection). Furthermore, in salmonid ovarian fluid, the prevalence or detection rate of DNA in the nested PCR assay and real-time PCR assay was higher than the detection rate of the mRNA. These results suggest that a portion of the PCR-positive samples would be false-positive with respect to detection of viable $R$. salmoninarum cells because the real-time PCR assay for mRNA did not show inhibition, therefore, detection rate by the assay would reflect that of viable bacteria. Thus, positive results of the PCR assay should be applied prudently for diagnostic and screening purposes of infected fish to control for BKD by culling or segregating those infected. The presence of gene DNA does not always indicate the presence of viable or culturable bacterial cells because DNA persists in actively killed bacterial cells for a significant period of time (Masters et al. 1994) and also persists in a PCR-detectable form in culture-negative environmental samples (Deere et al. 1996) and clinical samples (Hellyer et al. 1999). Thus, PCR methods to detect bacterial DNA can produce false-positive results through the amplification of target DNA from nonviable bacteria (Josephson et al. 1993, Masters et al. 1994, Sheridan et al. 1998, Keer \& Birch 2003). Miriam et al. (1997) reported that PCR for msa gene DNA identified much higher numbers in kidney and ovarian fluid samples from commercially reared Atlantic salmon to be positive than did culture and that this may have been due to antibiotic therapy of fish during the previous year.

Acknowledgements. The authors thank the staff of the Hokkaido Fish Hatchery for supplying experimental fish and the staff of the Hokkaido Salmon Propagation Association for supplying chum salmon ovarian fluid samples.

\section{LITERATURE CITED}

Alifano P, Bruni CB, Calromango MS (1994) Control of mRNA processing and decay in prokaryotes. Genetica 94:157-172

Armstrong RD, Martin SW, Evelyn TPT, Hicks B, Dorward WJ, Ferguson HW (1989) A field evaluation of an indirect fluorescent antibody-based broodstock screening test used to control the vertical transmission of Renibacterium salmoninarum in chinook salmon (Oncorhynchus tshawytscha). Can J Vet Res 53:385-389

Arraiano CM, Yancey SD, Kushner SR (1988) Stabilization of discrete mRNA breakdown products in ams pnp rnb multiple mutants of Escherichia coli K-12. J Bacteriol 170: 4625-4633

Austin B, Embley TM, Goodfellow M (1983) Selective isolation of Renibacterium salmoninarum. FEMS Microbiol Lett 17: 111-114

Belasco JG (1993) mRNA degradation in prokaryotic cells: an overview. In: Belasco J, Braorman G (eds) Control of messenger RNA stability. Academic Press, San Diego, CA, p 3-12

Belasco JG, Nilsson G, von Gabain A, Cohen SN (1986) The stability of E. coli transcripts is dependent on determinants localized to specific mRNA segments. Cell 46:245-251

Benediktsdóttir E, Gudmundsdóttir S, Helgason S (1991) Incubation time for the cultivation of Renibacterium salmoninarum from Atlantic salmon, Salmo salar L., broodfish. J Fish Dis 14:97-102

Birch L, Dawson CE, Cornett JH, Keer JT (2001) A compari- 
son of nucleic acid amplification techniques for the assessment of bacterial viability. Lett Appl Microbiol 33:296-301

Brown LL, Iwama GK, Evelyn TPT, Nelson WS, Levine RP (1995) Bacterial species other than Renibacterium salmoninarum cross-react with antisera against $R$. salmoninarum but are negative for the p57 gene of $R$. salmoninarum as detected by the polymerase chain reaction. Dis Aquat Org 21:227-231.

Chase DM, Pascho RJ (1998) Development of a nested polymerase chain reaction for amplification of a sequence of the p57 gene of Renibacterium salmoninarum that provides a highly sensitive method for detection of the bacterium in salmonid kidney. Dis Aquat Org 34:223-229

Chase DM, Elliott DG, Pascho RJ (2006) Detection and quantification of Renibacterium salmoninarum DNA in salmonid tissues by real-time quantitative polymerase chain reaction analysis. J Vet Invest 18:375-380.

Chien MS, Gilbert TL, Huang C, Landolt ML, O'Hara PJ, Winton JR (1992) Molecular cloning and sequence analysis of the gene of the salmonid fish pathogen Renibacterium salmoninarum. FEMS Microbiol Lett 96:259-266

Cook M, Lynch WH (1999) A sensitive nested transcriptase PCR assay to detect viable cells of the fish pathogen Renibacterium salmoninarum in Atlantic salmon (Salmo salar L.). Appl Environ Microbiol 65:3042-3047

Cvitanich JD (1994) Improvements in the direct fluorescent antibody technique for the detection, identification, and quantification of Renibacterium salmoninarum in salmonid kidney smears. J Aquat Anim Health 6:1-12

Deere D, Porter J, Pickup RW, Edwards C (1996) Survival of cells and DNA of Aeromonas salmonicida released into aquatic microcosms. J Appl Bacteriol 81:309-318

Elliott DG, Barila TV (1987) Membrane filtration-fluorescent antibody staining procedure for detecting and quantifying Renibacterium salmoninarum in coelomic fluid of chinook salmon (Oncorhynchus tshawytscha). Can J Fish Aquat Sci 44:206-210

Evelyn TPT (1977) An improved growth medium for the kidney disease bacterium and some notes on using the medium. Bull Off Int Epiz 87:511-513

Evelyn TPT, Ketcheson JE, Prosperi-Porta L (1981) The clinical significance of immunofluorescent-based diagnoses of the bacterial kidney disease carrier. Fish Pathol 15:293-300

Evenden AJ, Grayson TH, Gilpin ML, Munn CB (1993) Renibacterium salmoninarum and bacterial kidney diseasethe unfinished jigsaw. Annu Rev Fish Dis 3:87-104

Fryer JL, Sanders JE (1981) Bacterial kidney disease of salmonid fish. Annu Rev Microbiol 35:273-298

Grayson TH, Cooper LF, Atienzar FA, Knowles MR, Gilpin ML (1999) Molecular differentiation of Renibacterium salmoninarum isolates from worldwide locations. Appl Environ Microbiol 65:961-968

Grayson TH, Cooper LF, Wrathmell AB, Roper J, Evenden AJ, Gilpin ML (2002) Host responses to Renibacterium salmoninarum and specific components of the pathogen reveal the mechanisms of immune suppression and activation. Immunology 106:273-283

Griffiths SG, Olivier G, Fildes J, Lynch WH (1991) Comparison of western blot, direct fluorescent antibody and dropplate culture methods for the detection of Renibacterium salmoninarum in Atlantic salmon (Salmo salar L.). Aquaculture 97:117-129

Griffiths SG, Liska K, Lynch WH (1996) Comparison of kidney tissue and ovarian fluid from broodstock Atlantic salmon for detection of Renibacterium salmoninarum, and use of SKDM broth culture with Western blotting to increase detection in ovarian fluid. Dis Aquat Org 24:3-9
Gudmundsdóttir S, Benediktsdóttir E, Helgason S (1993) Detection of Renibacterium salmoninarum in salmonid kidney samples: a comparison of results using doublesandwich ELISA and isolation on selective medium. J Fish Dis 16:185-195

Gueimonde M, Tölkkö S, Korpimäki T, Salminen S (2004) New real-time PCR procedure for quantification of bifidobacteria in human fecal samples. Appl Environ Microbiol 70 : 4165-4169

Hein I, Lehner A, Rieck P, Klein K, Brandl E, Wagner M (2001) Comparison of different approaches to quantify Staphylococcus aureus cells by real-time quantitative PCR and application of this technique for examination of cheese. Appl Environ Microbiol 67:3122-3126

Hellyer TJ, DesJardin LE, Hehman GL, Cave MD, Eisennach KD (1999) Quantitative analysis of mRNA as a marker for viability of Mycobacterium tuberculosis. J Clin Microbiol 37:290-295.

Izumi S, Wakabayashi H (2000) Sequencing of gyrB and their application in the identification of Flavobacterium psychrophilum by PCR. Fish Pathol 35:93-94

Josephson KL, Gerba CP, Pepper IL (1993) Polymerase chain reaction of nonviable bacterial pathogens. Appl Environ Microbiol 59:3513-3515

Jou NT, Yoshimori RB, Mason GR, Louie JS (1997) Singletube, nested, reverse transcriptase PCR for detection of viable Mycobacterium tuberculosis. J Clin Microbiol 35: 1161-1165

Keer JT, Birch T (2003) Molecular methods for the assessment of bacterial viability. J Microbiol Methods 53:175-183

Kimura T, Yoshimizu M (1981) Rapid method for detection of bacterial kidney disease (BKD) by coagglutination of antibody sensitized protein A-containing Staphylococci. Bull Jpn Soc Sci Fish 47:1173-1183

Kimura T, Yoshimizu M, Hara T (1987) Diagnostic procedures for the bacterial kidney disease of salmonids. In: Suisanzosyoku-sousyo, 35. Jpn Resour Conserv Assoc, Tokyo (In Japanese with English summary)

Kushner SR (1996) mRNA decay. In: Neidhardt FC, Curtiss R, Ingraham JL, Lin ECC, Low KB, Magasanik B, Reznikoff WS, Riley R, Schaechter M, Umbarger HE (eds) Escherichia coli and Salmonella: Cellular and molecular biology, vol. 1, Am Soc Microbiol, Washington, DC, p 849-860

Lovely JE, Cabo C, Griffith SG, Lynch WH (1994) Detection of Renibacterium salmoninarum infection on asymptomatic Atlantic salmon. J Aquat Anim Health 6:126-132

Masters CI, Shallcross JA, Mackey BM (1994) Effect of stress treatments on the detection of Listeria monocytogenes and enterotoxigenic Escherichia coli by the polymerase chain reaction. J Appl Bacteriol 77:73-79

McIngvale SC, Elhanafi D, Drake MA (2002) Optimization of reverse transcription PCR to detect viable shiga-producing Escherichia coli. Appl Environ Microbiol. 68: 799-806.

McIntosh D, Meaden PG, Austin B (1996) A simplified PCRbased method for the detection of Renibacterium salmoninarum using preparations of rainbow trout (Oncorhynchus mykiss, Walbaum) lymphocytes. Appl Environ Microbiol 62:3929-3932

Miriam A, Griffith SG., Lovely JE, Lynch WH (1997) PCR and probe-PCR assays to monitor broodstock Atlantic salmon (Salmo salar L.) ovarian fluid and kidney tissue for presence of DNA of the fish pathogen. J Clin Microbiol 35: $1322-1326$

Nogva HK, Rudi K, Naterstad K, Holck A, Lillehaug D (2000) Application of 5 '-nuclease PCR for quantitative detection of Listeria monocytogenes in pure culture, water, skim milk, 
and unpasteurized whole milk. Appl Environ Microbiol 66: 4266-4271

O'Farrell CL, Strom MS (1999) Differential expression of the virulence-associated protein p57 and characterization of its duplicated gene msa in virulent and attenuated strains of Renibacterium salmoninarum. Dis Aquat Org 38:115-123

O'Hara EB, Chekanova JA, Ingle CA, Kushner ZR, Peters E, Kushner SR (1995) Polyadenylation helps regulate mRNA decay in Escherichia coli. Proc Natl Acad Sci USA 92: 1807-1811

Olea I, Bruno DW, Hastings TS (1993) Detection of Renibacterium salmoninarum in naturally infected Atlantic salmon, Salmo salar L., and rainbow trout, Oncorhynchus mykiss (Walbaum) using an enzyme-linked immunosorbent assay. Aquaculture 116:99-110

Olivier G, Griffiths SG, Fildes J, Lynch WH (1992) The use of western blot and electroimmunotransfer blot assays to monitor bacterial kidney disease in experimentally challenged Atlantic salmon, Salmo salar L. J Fish Dis 15:229-241

Pascho RJ, Mulcahy D (1987) Enzyme-linked immunosorbent assay for a soluble antigen of Renibacterium salmoninarum, the causative agent of salmonid bacterial kidney disease. Can J Fish Aquat Sci 44:183-191

Pascho RJ, Chase D, McKibben CL (1998) Comparison of the membrane-filtration fluorescent antibody test, the enzymelinked immunosorbent assay, and the polymerase chain reaction to detect Renibacterium salmoninarum in salmonid ovarian fluid. J Vet Diagn Invest 10:60-66

Pascho RJ, Elliott DG, Streufert JM (1991) Brood stock segregation of spring chinook salmon Oncorhynchus tshawytscha by use of the enzyme-linked immunosorbent assay (ELISA) and the fluorescent antibody technique (FAT) affects the prevalence and levels of Renibacterium salmoninarum infection in progeny. Dis Aquat Org 12:25-40

Powell M, Overturf K, Hogge C, Johnson K (2005) Detection of Renibacterium salmoninarum in chinook salmon, Oncorhynchus tshawytscha (Walbaum), using quantitative PCR. J Fish Dis 28:615-622

Rauhut R, Klug G (1999) mRNA degradation in bacteria. FEMS Microbiol Rev 23:353-370.

Requena $\mathrm{T}$, Burton J, Matsuki T, Munro K, Simon MA, Tanaka R, Watanabe K, Tannock GW (2002) Identification, detection, and enumeration of human bifidobacterium species by PCR targeting the transaldolase gene. Appl Environ Microbiol 68:2420-2427

Rhodes LD, Alison MC, Deinhand RK (2004) Identification of a third msa gene in Renibacterium salmoninarum and the associated virulence phenotype. Appl Environ Microbiol 70:6488-6494

Rhodes LD, Durkin C, Nance SL, Rice CA (2006) Prevalence and analysis of Renibacterium salmoninarum infection

Editorial responsibility: David Bruno,

Aberdeen, UK among juvenile Chinook salmon Oncorhynchus tshawytscha in North Puget Sound. Dis Aquat Org 71:179-190

Rockey DO, Gilkey LL, Wiens GD, Kaattari SL (1991) Monoclonal antibody-based analysis of the Renibacterium salmoninarum p57 protein in spawning chinook and coho salmon. J Aquat Anim Health 3:23-30

Rodríguez-Lázaro D, Hernández M, Scortti M, Esteve T, Vázquez-Boland JA, Pla M (2004) Quantitative detection of Listeria monocytogenes and Listeria innocua by realtime PCR: assessment of hly, jap, and lin02483 targets and AmpliFluor technology. Appl Environ Microbiol 70: 1366-1377

Sakai DK, Nagata N, Iwama T, Tamiya Y, Ito Y, Atoda M (1986) Attempt to control BKD by dietary modification and erythromycin chemotherapy in hatchery-reared masu salmon Oncorhynchus masou Brevoort. Bull Jpn Soc Sci Fish 52: 1141-1147

Sakai M, Atsuta S, Kobayashi M (1991) Susceptibility of five salmonid fishes to Renibacterium salmoninarum. Fish Pathol 26:159-160

Sheridan GE, Masters CI, Shallcross JA, Mackey BM (1998) Detection of mRNA by transcription-PCR as an indicator of viability in Escherichia coli cells. Appl Environ Microbiol 64:1313-1318

Starliper CE (1996) Genetic diversity of North American isolates of Renibacterium salmoninarum. Dis Aquat Org 27: 207-213

Steege DA (2000) Emerging features of mRNA decay in bacteria. RNA (NY) 6:1079-1090

Toyama T, Kita-Tsukamoto K, Wakabayashi H (1994) Identification of Cytophaga psychrophila by PCR $16 \mathrm{~S}$ ribosomal RNA. Fish Pathol 29:271-275

Turuga PSD, Wiens GD, Kaattari SL (1987) Analysis of Renibacterium salmoninarum antigen production in situ. Fish Pathol 22:209-214

Von Gabain A, Belasco JG, Scottel JL, Chang ACY, Cohen SN (1983) Decay of mRNA in Escherichia coli: investigation of the fate of specific segments of transcripts. Proc Natl Acad Sci USA 80:653-657

Wakabayashi H, Egusa S (1974) Characteristics of myxobacteria associated with some freshwater fish diseases in Japan. Bull Jpn Soc Sci Fish 13:751-757

Wiens GD, Kaattari SL (1989) Monoclonal antibody analysis of common surface protein(s) of Renibacterium salmoninarum. Fish Pathol 24:1-7

Wiens GD, Pascho RJ, Winton JR (2002) A single Ala ${ }^{139}$-toGlu substitution in the Renibacterium salmoninarum virulence-associated protein p57 results in antigenic variation and is associated with enhanced p57 binding to chinook salmon leukocytes. Appl Environ Microbiol 68: 3969-3977

Submitted: August 21, 2006; Accepted: November 17, 2006 Proofs received from author(s): February 27, 2007 